Florida International University

FIU Digital Commons

FIU Electronic Theses and Dissertations

University Graduate School

$2-20-2018$

\title{
The Relationship Between District Concert Band Music Performance Assessment Participation and Student Achievement in Miami-Dade County Public Middle Schools
}

Arthur J. N. Scavella

Florida International University, ascav001@fiu.edu

DOI: $10.25148 /$ etd.FIDC006579

Follow this and additional works at: https://digitalcommons.fiu.edu/etd

Part of the Educational Assessment, Evaluation, and Research Commons, Educational Leadership Commons, Elementary and Middle and Secondary Education Administration Commons, Music Education Commons, Music Performance Commons, Other Educational Administration and Supervision Commons, and the Urban Education Commons

\section{Recommended Citation}

Scavella, Arthur J. N., "The Relationship Between District Concert Band Music Performance Assessment Participation and Student Achievement in Miami-Dade County Public Middle Schools" (2018). FIU Electronic Theses and Dissertations. 3638.

https://digitalcommons.fiu.edu/etd/3638

This work is brought to you for free and open access by the University Graduate School at FIU Digital Commons. It has been accepted for inclusion in FIU Electronic Theses and Dissertations by an authorized administrator of FIU Digital Commons. For more information, please contact dcc@fiu.edu. 


\section{FLORIDA INTERNATIONAL UNIVERSITY \\ Miami, Florida}

\section{THE RELATIONSHIP BETWEEN DISTRICT CONCERT BAND \\ MUSIC PERFORMANCE ASSESSMENT PARTICIPATION AND \\ STUDENT ACHIEVEMENT IN \\ MIAMI-DADE COUNTY PUBLIC MIDDLE SCHOOLS}

A dissertation submitted in partial fulfillment of

the requirements for the degree of

DOCTOR OF EDUCATION

in

EDUCATIONAL ADMINISTRATION AND SUPERVISION

by

Arthur James Napoleon Scavella

2018 
To: Dean Michael R. Heithaus

College of Arts, Sciences \& Education

This dissertation, written by Arthur James Napoleon Scavella, and entitled The Relationship Between District Concert Band Music Performance Assessment Participation and Student Achievement in Miami-Dade County Public Middle Schools, having been approved in respect to style and intellectual content, is referred to you for judgment.

We have read this dissertation and recommend that it be approved.

$\begin{array}{r}\text { Isaac Burt } \\ \hline \text { Charmaine DeFrancesco } \\ \hline \text { Peter J. Cistone, Co-Major Professor } \\ \hline \text { Thomas G. Reio, Jr., Co-Major Professor }\end{array}$

Date of Defense: February 20, 2018

The dissertation of Arthur James Napoleon Scavella is approved.

Dean Michael R. Heithaus

College of Arts, Sciences \& Education

Andrés G. Gil

Vice President for Research and Economic Development and Dean of the University Graduate School

Florida International University, 2018 
(C) Copyright 2018 by Arthur James Napoleon Scavella

All rights reserved. 


\section{DEDICATION}

To my parents, Gloria P. Scavella and the late Winston D. Scavella; thank you for believing in me and guiding me throughout my life to beat all odds. 


\section{ACKNOWLEDGMENTS}

A sincere debt of gratitude goes to my major professor, Dr. Peter J. Cistone. He has guided me throughout my entire graduate school experience and has played an integral part in guiding me to this point of success and completion of my doctoral studies. For his guidance as well as his wealth of knowledge in the field, I am forever grateful.

I would like to thank Dr. Thomas G. Reio for his guidance throughout the dissertation process as well. His patience and guidance assisted me with the process of writing and successfully completing my dissertation and I owe him a wealth of gratitude.

I would also like to thank Dr. Isaac Burt, Dr. Charmaine DeFrancesco, and Dr. Angela Salmon for their wealth of knowledge and different perspectives to my research topic. I am thankful that they took an interest in my study and provided me continued support throughout this stage of my doctoral studies.

Special thanks go to the principals, administrators, band directors, and teachers throughout the Miami-Dade County Public School System that agreed to assist me with the data collection in order to make this study possible; for without them, this study would not have been possible.

Finally, I would like to thank Sharria and Earline; I am grateful that they were my motivation throughout this colossal task. When things got tough, they continued to push and motivate me to the end and I will forever be grateful. 


\author{
ABSTRACT OF THE DISSERTATION \\ THE RELATIONSHIP BETWEEN DISTRICT CONCERT BAND MUSIC \\ PERFORMANCE ASSESSMENT PARTICIPATION AND STUDENT \\ ACHIEVEMENT IN \\ MIAMI-DADE COUNTY PUBLIC MIDDLE SCHOOLS
}

by

Arthur James Napoleon Scavella

Florida International University, 2018

Miami, Florida

Professor Peter J. Cistone, Co-Major Professor

Professor Thomas G. Reio, Co-Major Professor

Since the implementation and achievement score pressures of the No Child Left

Behind Act of 2001, elective course offerings such as music have been drastically reduced, especially in the middle school setting. A great deal of correlational research has shown a positive correlation between music education in school and students' overall academic achievement.

This study examined the correlation between those middle school students that participated in the District Concert Band Music Performance Assessment (MPA) versus those middle school students that did not regarding their achievement scores on the 2016 English language arts (ELA) and mathematics subtests of the Florida Standards Assessments (FSA). The theoretical framework of this study was undergirded by Howard Gardner's theory of multiple intelligences. 
The researcher used a non-experimental ex post facto research design for the collection of the study's data. The results indicated that there was a positive, statistically significant difference between both the ELA and mathematics achievement scores of those students that participated in the MPA and those that did not. There was also a positive, statistically significant difference between both the ELA and mathematics achievement scores of those students that participated in the MPA and the level of music their band performed. However, there was not a statistically significant difference between both the ELA and mathematics achievement scores of those students that performed at the MPA and the final overall rating that their band received.

School administrators are charged with the responsibility of ensuring that effective programs are instituted in their schools so their students can be successful. The results of this quantitative non-experimental ex post facto study could provide administrators additional research-based evidence suggesting that band on the middleschool level, which is a branch of music education, could be a program to include in the school's curriculum because it might positively contribute to the school's ELA and mathematics achievement and academic culture. Additional research can also be conducted to observe the effects of music study on student achievement for students of all grade levels and socioeconomics. This would lead school administrators to continue practicing the notion of educating the whole child while making administrative decisions, which should be the sine qua non of education. 


\section{TABLE OF CONTENTS}

CHAPTER

PAGE

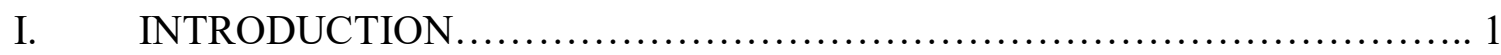

Music and Student Achievement................................... 1

Statement of the Problem.............................................. 3

Purpose of the Study.............................................. 5

Research Questions.............................................. 5

Limitations of the Study............................................ 6

Delimitations of the Study ............................................ 7

Significance of the Study ............................................. 8

Definitions and Operational Terms..................................... 11

II. REVIEW OF THE LITERATURE...................................... 14

An Overview on the History of Music Education in America............. 14

The Role of Middle School Education................................ 17

Theoretical Framework: Howard Gardner's Theory of Multiple

Intelligences..............................................20

The Benefits of Music Education to Student Achievement................24

The Mozart Effect.................................................. 25

Student Achievement in Reading and Mathematics......................30

Attendance, Graduation, and Social Skills .................................36

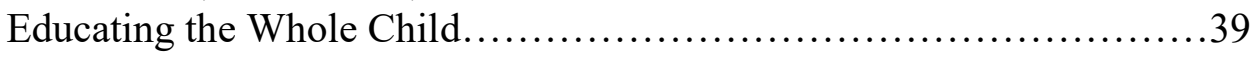

III. RESEARCH DESIGN AND METHODOLOGY ...........................43

Research Questions and Hypotheses..................................43

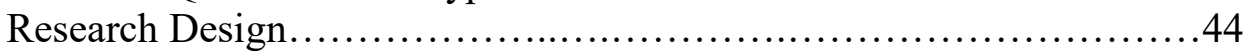

Population and Sample..........................................45

Research Variables................................................46

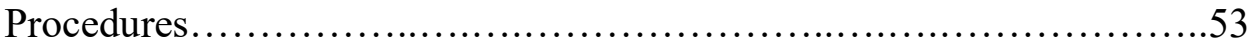

Statistical Treatment.............................................56

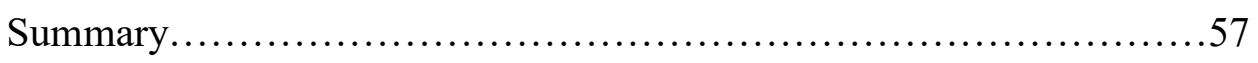

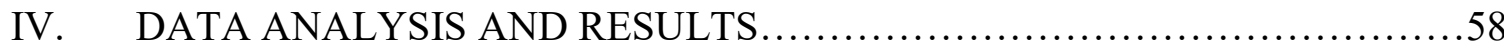

Descriptive Statistics............................................. 58

Inferential Statistics................................................ 71

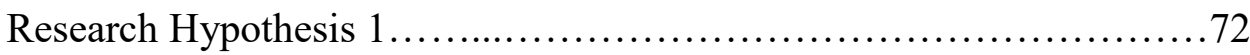

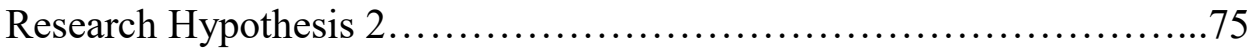

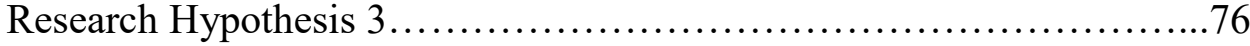

Summary ......................................................... 77

V. SUMMARY, CONCLUSIONS, AND IMPLICATIONS ........................79

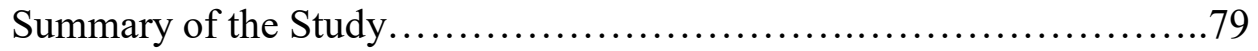

Discussion of the Results............................................. 81 
Discussion of Research Hypothesis $1 \ldots \ldots \ldots \ldots \ldots \ldots \ldots \ldots \ldots \ldots \ldots \ldots 1$

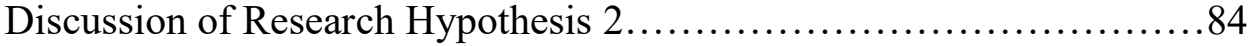

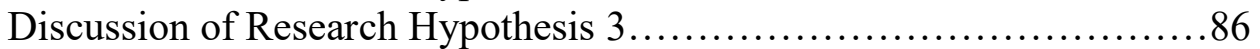

Implications.................................................... 87

Theoretical Implications......................................... 87

Research Implications.......................................... 88

Implications for Practice.......................................89

Recommendations for Further Research................................8 89

Summary............................................... 91

REFERENCES...........................................................93

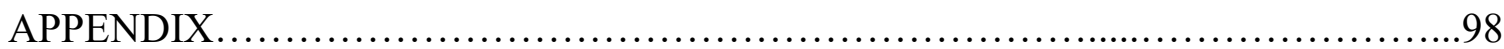

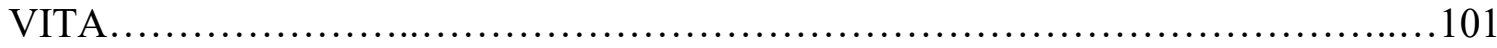




\section{LIST OF TABLES}

TABLE

PAGE

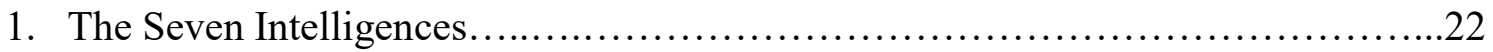

2. Intelligences Eight and Nine of the Theory of Multiple Intelligences...............23

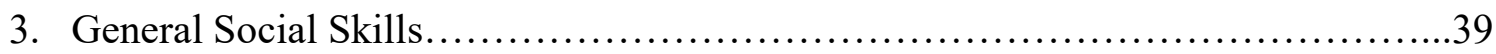

4. Classification Level Based on Seventh and Eighth Grade School Enrollment.........51

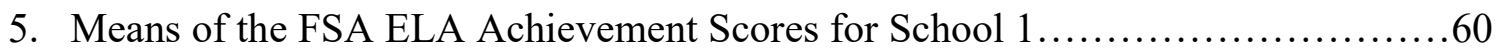

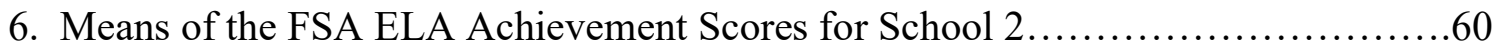

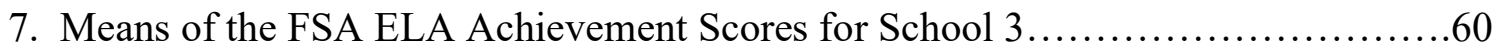

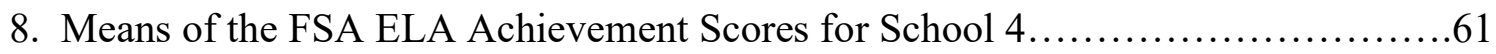

9. Means of the FSA Mathematics Achievement Scores for School $1 \ldots \ldots \ldots \ldots \ldots \ldots . . .61$

10. Means of the FSA Mathematics Achievement Scores for School 2...............61

11. Means of the FSA Mathematics Achievement Scores for School 3...............62

12. Means of the FSA Mathematics Achievement Scores for School 4................62

13. Means of the FSA ELA and Mathematics Achievement Scores for The High-

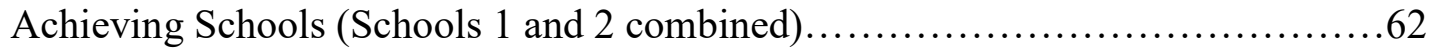

14. Means of the FSA ELA and Mathematics Achievement Scores for The Low-

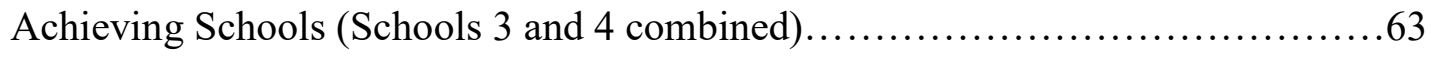

15. Means of the FSA ELA Achievement Scores for All Four Schools Combined......63

16. Means of the Mathematics Achievement Scores for All Four Schools Combined...63

17. Independent-Samples t-Test of the Students' ELA and Mathematics Achievement Scores from the High-Achieving Schools and Concert Band MPA Participation......73

18. Independent-Samples t-Test of the Students' ELA and Mathematics Achievement Scores from the Low-Achieving Schools and Concert Band MPA Participation......73 
19. Independent-Samples t-Test of the Students' ELA and Mathematics Achievement Scores from All of the Schools Combined and Concert Band MPA Participation...74

20. Independent-Samples t-Test of the Students' ELA and Mathematics Achievement Scores and the Level of Music Performed at the Concert Band MPA.................76

21. Independent-Samples t-Test of the Students' ELA and Mathematics Achievement Scores and the Final Overall Rating that their Band Received at the Concert Band

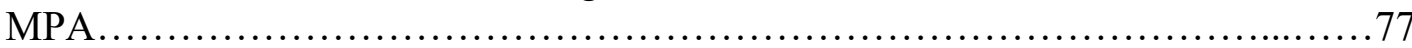




\section{LIST OF FIGURES}

FIGURE

PAGE

1. Example of the paper folding and cutting task used in the spatial reasoning test.......26

2. The possible combinations of the ratings of the three adjudicators from the prepared pieces performance............................................. 50

3. The derivation of the band's overall (final) rating: averaging of a band's prepared pieces rating received from Figure 2 and the sightreading rating...............50

4. Box plot illustrating the distribution of the ELA scores for School $1 \ldots \ldots \ldots \ldots \ldots . . .64$

5. Box plot illustrating the distribution of the mathematics scores for School $1 \ldots \ldots . . .65$

6. Box plot illustrating the distribution of the ELA scores for School 2...............65

7. Box plot illustrating the distribution of the mathematics scores for School 2........66

8. Box plot illustrating the distribution of the ELA scores for School 3..............66

9. Box plot illustrating the distribution of the mathematics scores for School 3........67

10. Box plot illustrating the distribution of the ELA scores for School $4 \ldots \ldots \ldots \ldots \ldots . . .67$

11. Box plot illustrating the distribution of the mathematics scores for School 4........68

12. Box plot illustrating the distribution of the ELA scores for the high-achieving

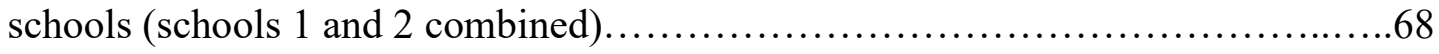

13. Box plot illustrating the distribution of the ELA scores for the low-achieving schools (schools 3 and 4 combined).

14. Box plot illustrating the distribution of the mathematics scores for the high-achieving schools (schools 1 and 2 combined).

15. Box plot illustrating the distribution of the mathematics scores for the low-achieving schools (schools 3 and 4 combined)

16. Box plot illustrating the distribution of the ELA scores for all four schools

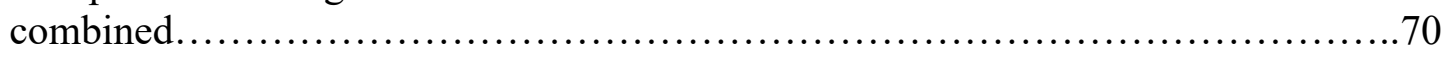

17. Box plot illustrating the distribution of the mathematics scores for all four schools combined. 


\section{CHAPTER I}

\section{INTRODUCTION}

According to a Gallup Poll conducted and reported by the American Music Conference (2003): "95\% of Americans believe that music is a key component in a child's well-rounded education...more than three quarters of those surveyed feel school should mandate music education" (p. 70). This notion of Americans' beliefs on the importance of music education dates back to when Horace Mann, a founding advocate of public education, along with Lowell Mason, pushed for music inclusion in the core curriculum because of the belief that music is an important dimension of academic development (Southgate \& Roscigno, 2009).

\section{Music and Student Achievement}

"Hong Kong as well as Japan, Canada, Finland, and five other countries that consistently outperform us in math and reading all require extensive education in the arts without narrowing their curriculum, according to a 2010 report from Common Core, a Washington, DC, educational research and advocacy organization" (Kalish, 2010, para. 5). The arts, particularly music instruction in schools, are believed to be an important curriculum piece in improving students' reading comprehension and mathematics skills.

"Students who incorporate music performance or appreciation into their curriculum perform better in academic subjects, score higher on the SAT's, and have a higher level of self-esteem; many children find their hidden talents when they pick up a musical instrument or open a songbook" (Goodlatte, 2001, p. 15). There is research that suggests the preceding assertion, referring to standardized testing and student

achievement in school. Music involvement has been publicly correlated to student 
achievement; this connection has been made as a result in debates over cuts to elementary, middle school, and high school music programs (Southgate \& Roscigno, 2009).

Gromko (2005) asserted that the ability to read and write with understanding enhances children's interpersonal communication, expands their worlds, and leads to independence in learning; therefore, it is not surprising that literacy and reading comprehension are issues of national concern. Gromko's (2005) correlational study may suggest that music instruction is an important component of a young child's education because of the notion presented in his study that music can enhance a child's phonemic awareness development early on in life, which could help reduce the number of students struggling with reading skills.

Presently, educators are now held fully accountable for the successes of its students with specific learning disability (SLD) population, such as those with dyslexia, dysgraphia, and dyscalculia. Register, Darrow, Standley, and Swedberg (2007) provide the fact that literacy acquisition is a primary focus among educators. The SLD category has the greatest incidence of any of the special education areas such as autism, language impairment, and the like, and is the designation for funding and remediation of reading problems (Foorman, Fletcher, \& Francis, 1997; Register et al., 2007). As educators are becoming increasingly accountable for the successful achievement of students with SLD on standardized testing, based on Gromko's (2005) correlational study for example, it could be inferred that music instruction can be infused in the total curriculum to assist students with SLD in improving their reading skills. 
In addition to the notion that there is a positive correlation between music and reading achievement in students, there is also research, which suggests that music also enhances mathematics achievement as well. The connection between music and cognitive benefits, especially in mathematics skills, is generally traced to the ancient Greek, Pythagoras, who in the fifth century BCE suggested that mathematical relationships were integral to physical properties, including music (Southgate \& Roscigno, 2009).

The ultimate goal for students in the K-12 educational setting is graduation from high school. Fehr (2006) mentions that nationwide, school principals agree that highquality music education is important for students' educational success. The principals interviewed for that study agreed that participating in music education encouraged students to stay in school and a high-quality music education program contributed to their schools achieving higher graduation rates (Fehr, 2006).

\section{Statement of the Problem}

Rothstein (2008) suggested that under No Child Left Behind (NCLB), reliance solely on numerical measures, mainly mathematics and reading scores to evaluate performance, has corrupted schooling. Educators responding to the need to devote more time to mathematics and reading have led to significant reductions in the time spent on social studies, science, art, music, physical education, cooperative learning, and other character-building activities.

Rothstein (2008) also suggested that significant reductions of music instruction have been most severe for disadvantaged students who are most in need of a balanced curriculum. Schools now focus on "bubble" students (those just below the proficiency 
point according to standardized testing) to the detriment of students who are far behind or already above proficiency. Rothstein (2008) asserted, "accountability for an unreliable single test score resulted in arbitrary classifications of some fine schools as failing, and some poor schools as adequate" (p.15).

Due to the increasing high stakes testing and budget pressures that are imposed on today's schools, it is important to continue the advocacy efforts of music education in the schools, emphasizing the research which suggests that there is a positive correlation between music being a part of the schools' curriculum and high student achievement. School administrators need to be kept abreast of the significance and advantages of having music within their school's curriculum, because they are decision makers in their respective schools in respect to which courses are offered within the school's curriculum.

In Abril and Gault's (2008) study, the results showed that No Child Left Behind (NCLB) and high-stakes, standardized tests had the most negative impact on music programs. This is due to music class time being drastically reduced because of highstakes testing pressures. Three other negative effects on music education were budgeting, scheduling, and standardized tests. The principals' perspectives of variables impacting music education negatively were financial/budgetary, scheduling/time, outside pressures (legislation, testing), staffing, unique characteristics of the school (decreasing enrollment, socioeconomic status), and facilities/equipment (Abril \& Gault, 2008).

Abril and Gault (2008) reiterated the notion that school and district administrators are highly influential in determining what course offerings are made available to students. Therefore, information regarding their attitudes and perceptions of music programs can help music educators, arts administrators, and policy makers make informed decisions in 
the quest to ensure the music program remains a viable facet of the overall school curriculum. The current research implying the link between music education and student achievement is still in its developing stages and this dissertation will seek to add on to the body of knowledge, which suggests the positive correlation between music study and student academic achievement.

\section{Purpose of the Study}

Advocacy for school music goes back at least to Lowell Mason, who in 1838 persuaded the Boston School Committee to include music as a curricular subject (Mark, 2002). As standardized testing and budget pressures increase in today's schools, so does the advocacy effort of keeping music education in schools. Advocacy has continually informed society, including parents, and policymakers of the value of music education in the schools (Mark, 2002). Due to the notion that middle schools across the country exhibit the largest instance of an achievement gap when a student transitions from elementary to middle school (West \& Schwerdt, 2012), the middle school level was the focus of this study.

Given these findings in the literature, the purpose of this study was to explore the relationship between middle school students that participate in the yearly Florida Bandmasters Association (FBA) District Concert Band Music Performance Assessment (MPA) and student achievement on the English language arts (ELA) and mathematics subtests of the Florida Standards Assessments (FSA).

\section{Research Questions}

This study was designed to answer the following question: Is there a statistically significant difference in student achievement on the 2016 Florida Standards Assessments 
(FSA) English Language Arts (ELA) and mathematics subtests between those Miami-

Dade County Public middle school students that participate in the 2016 District Concert Band Music Performance Assessment (MPA), and those who do not? This primary research question was answered by answering the following research questions:

1. Is there a correlation between a middle school student's District Concert Band MPA participation and FSA ELA and Mathematics achievement scores?

Further research was also conducted by answering the following two sub-questions:

2. For the middle school students that did participate in the District Concert Band MPA, is there a correlation between ELA and Mathematics achievement scores and the level of music performed?

3. For the middle school students that did participate in the District Concert Band MPA, is there a correlation between ELA and Mathematics achievement scores and their band's overall rating received?

\section{Limitations of the Study}

Limitations of the study included the notion that the findings could perhaps be generalized to a similar school district, which includes a diverse, multi-cultural population, similar to that of Miami-Dade County Public Schools, but not necessarily to ALL school districts across the country, as a number of those districts do not have a similar multi-cultural population. Multi-cultural populations include various socioeconomic and ethic differences; these differences are also widespread across the Miami-Dade County Public School System and this could affect the generalizability of the study's findings. 
The study included four traditional, feeder pattern Miami-Dade County Public Middle Schools, which consisted of students in Grades 6-8. Two of the schools were high-achieving schools with an active, established band program and the other two schools were low-achieving schools with an active, established band program. A highachieving school is defined as a school that is consistently designated as Grade A or B by the State of Florida Department of Education for at least the past two consecutive school years (2013-2014, 2014-2015 school year). A low-achieving school is defined as a school that is consistently designated as Grade C, D, or F by the State of Florida Department of Education for at least the past two consecutive school years (2013-2014, 2014-2015 school year). The reason for this particular two-year span is because prior to the 2013-2014 school year, a different standardized test was used in the State of Florida.

Generalizability may be an issue for private and charter middle schools, due to the notion that oftentimes, students are hand-selected for these types of schools, which usually consist of high-performing students to begin with. A limitation also included the quality of the band director. Additionally, the cross comparison of data was not possible because the students' gender was not available to the researcher, which could influence the data. The only data that was available to the researcher was the students' participation versus nonparticipation and their FSA achievement scores. The study's findings could show a correlation between music and student achievement, but it cannot necessarily infer causation.

\section{Delimitations of the Study}

Although it would have been ideal to study the link between music participation and academic achievement in all schools, the research of this study focused on four 
traditional, feeder pattern middle schools in the largest, urban Florida school district, where so little music education research has been conducted. Even though research suggests that music education as a whole improves student achievement on all school levels, the study only focused on middle school band. The researcher chose band as the music education branch to use for the study because on the middle school level, more students are exposed to and involved with band than any of the other music education branches in the State of Florida (Florida School Music Association, n.d.).

Since middle schools across the country exhibit the largest instance of an achievement gap when a student transitions from elementary to middle school (West \& Schwerdt, 2012), one of the purposes of this study was to support the notion of "educating the whole child," in which research suggested it to be as the most effective method of educating students, and this is crucial on the middle school level (Ediger, 2006; Noddings, 2005). Another purpose of this study was to explore the positive relationship a band program can have on a middle school's overall academic achievement and academic environment. For middle schools that have an active, established band program, which is indicated by their participation in the District Concert Band Music Performance Assessment, it could be inferred that these schools foster the notion of educating the whole child. The notion of educating the whole child will be expounded upon in the literature review.

\section{Significance of the Study}

Educators and administrators alike are constantly exploring pedagogical methods to most effectively educate students. Increased high-stakes testing pressures on schools create a greater need for educators to be more knowledgeable about promising, useful 
ways of educating students. The significance of this study was to contribute to the body of literature, which suggests that music education can contribute to the positive overall academic environment of a school as evidenced by student achievement.

One of the most notable figures in the study of pedagogy is Howard Gardner. He developed the theory of multiple intelligences; his theory is introduced in teacher preparation programs in colleges and universities across the country and is considered an important pedagogical construct. Gardner developed this theory because, just like standardized tests, education seemed to have placed overemphasis on reading and mathematics; however, as a psychologist and neuropsychologist, he presented research that the human mind is more complex in nature (Gardner \& Hatch, 1989).

Gardner's theory of multiple intelligences, which will be further expounded upon in the literature review, presented nine intelligences; one of the nine intelligences of the theory is music. Music intelligence, according to his theory, runs in an almost structural parallel to linguistic and mathematical intelligences; these two intelligences are constantly assessed on standardized examinations (Gardner, 2011; McFarlane, 2011). This structural parallel could suggest that music can contribute to the positive overall academic environment and student achievement within a school.

As the literature review will present, there is a plethora of research that shows a positive correlation between music education in schools, high academic achievement, and standardized test scores. Correlational research has been conducted for both reading and mathematics standardized test scores and music study and the results showed positive correlation between music study in school and high student achievement. These findings led the researcher to investigate the relationship between a middle school student's 
participation in the District Concert Band Music Performance Assessment, which is a branch of music education, and that student's achievement on the Florida Standards Assessments (FSA).

Research also suggests schools that offer music programs have significantly higher attendance and graduation rates than those without music programs (Music Makes the Grade, 2007). Music education has also shown to positively impact students' social skills, in which Gooding (2009) suggested that strong social skills are vital for successful functioning in life. Social skills also tie into the notion of educating the whole child, in which Noddings (2005) suggested that schools must be concerned with the total development of children.

Historically, middle schools across the country exhibit the largest instance of an achievement gap when a student transitions from elementary to middle school (West \& Schwerdt, 2012). Additionally, middle schools are supposed to provide a curriculum that is challenging, integrative, and exploratory (This We Believe, 1995); an exploratory curriculum includes electives such as art and music. This is the time period of young adolescents' lives when they are supposed to discover their likes, dislikes, strengths, and weaknesses, and this was a time where students were typically placed on the college bound track or vocational track (Compton \& Hawn, 1993; Gilstrap, 1994; Manning, 2000).

Due to increased high stakes testing pressures on administrators and teachers alike, these exploratory electives have been drastically reduced, and in increased cases, eliminated from the middle school curricula; this includes the sharp decline of middle school band offerings within the school curricula. Educational curricula have shifted to 
increased offerings of intensive reading and mathematics courses for those students that are not on achievement level in accordance with standardized tests and these students are no longer afforded the opportunity to take exploratory elective courses. This reduction of elective offerings on the middle school level completely antagonizes the purpose of middle school education, as middle school education is intended to be exploratory in nature, in which an exploratory curriculum is considered as one of the most successful components of the middle school (Gilstrap, 1994).

School administrators are increasingly charged with the responsibility of raising their school's student achievement scores. This increases the necessity for administrators to have an increased knowledge of programs and strategies that can be used to raise their school's academic achievement. This notion contributes to the significance of this study: to determine if there is a link between middle school band programs (a branch of music education) and the students' positive academic performance. The further analysis of a band's overall rating and the level of music performed in the study could serve as an academic characteristic within the overall school setting, which could also inspire academic gains in other subject areas within the school (Johnson, 2004). If the results of this study are as hypothesized, it could be inferred that middle school band can be one of those programs to positively impact the academic culture and student academic performance within a middle school.

\section{Definitions and Operational Terms}

District concert band music performance assessment. Also known as District Concert Band MPA, the District Concert Band Music Performance Assessment is the yearly performance assessment that takes place in the spring for each school district 
throughout the State of Florida. All active, established middle school bands throughout each school district in the state participate in this yearly assessment. According to the Florida Bandmasters Association Website, the purpose of the District Concert Band MPA is to provide opportunities for students and directors to perform in an environment that provides critical evaluation of its performance by noted experts in the field of band performance, and to demonstrate students' abilities to apply musical fundamentals and concepts in an ensemble performance setting. The District Concert Band Music Performance Assessment is not a band competition; the bands do not compete against one another and each band is assessed and assigned a rating based on their performance on an individualized basis, which is used to measure the quality of the band program. Therefore, it is possible and typical for several bands to receive the same rating during the same assessment event.

Florida standards assessments. The Florida Standards Assessments (FSA) was created by the Florida Department of Education and is administered to all students in Grades 3 to 10 in the area of English Language Arts (ELA) and Grades 3 to 8 in Mathematics. It was designed for accountability purposes to ensure that all students were meeting standards that were aligned with the Sunshine State Standards, which are a set of competencies that each student is expected to know in accordance to their grade level.

Florida bandmasters association (FBA). According to The Florida Bandmasters Association website, the purpose of the FBA is to promote and develop band programs in the State of Florida by providing opportunities for in-service growth through clinics and conferences, and by acting as a resource for college and university pre-service training programs that encourage professional development. Furthermore, the 
FBA provides opportunity for realistic and constructive program evaluation through the sponsorship of solo/ensemble and large group ensemble Music Performance Assessments (MPAs) at the District and State levels. The FBA is responsible for producing and governing the District Concert Band Music Performance Assessments throughout the state.

Florida school music association (FSMA). According to the Florida School Music Association website, the purpose of the FSMA is to coordinate and oversee recognized interscholastic music activities in the State of Florida. These activities include the District Music Performance Assessments (MPAs). The Florida Bandmasters Association (FBA) operates under the umbrella of the FSMA and is governed by them. All schools across the state must be a member of the FSMA in order to participate in any music performance assessments. 


\section{CHAPTER II}

\section{REVIEW OF THE LITERATURE}

During the course of the past several decades, researchers have investigated the notion of the positive effects of music study in schools and student achievement. As high stakes testing and accountability pressures continue to increase in public schools, educators are constantly seeking different methods to help students become more and more successful on these examinations. Due to these increasing pressures of high stakes testing and accountability, programs such as music has seen a steadily decline in its availability to students in school, especially on the middle school level; middle schools across the country experience the highest case of a gaping achievement gap when a student transitions from elementary to middle school (West \& Schwerdt, 2012).

This study sought to contribute to the body of knowledge in relation to the benefits of music instruction and high student achievement. The following literature review gives an insight of the history of music education in America, the role of middle school education, Howard Gardner's multiple intelligences theoretical framework, music education's benefits to student achievement; attendance, graduation, and social skills; and educating the whole child.

\section{An Overview on the History of Music Education in America}

Since the Colonial time period in America, the development of the notion of music education was eminent (Mark, 1989). Mark (1989) gives an overview of the various time periods in relation to music education in America. During the Colonial time period in America, circa 1620, the use of music in church services declined drastically in quality and the need for music instruction was established. As a result, the singing school 
movement was developed to rectify this issue. According to Mark (1989), "the functions of the singing school were to establish both a formal mass music education system in the colonies that led to the development of public school music, and a cadre of professional music teachers" (p. 3).

In the beginning of the nineteenth century, music began to be taught in schools. At this time, public school music did not receive public funding and was not considered a curricular subject, but was the beginning of school music, as we know it today (Mark, 1989). In 1838, music was first introduced into the Boston public schools under the guidance of Lowell Mason and music was now considered as a curricular subject. Mason set the precedence of the spread of music as being a curricular subject into other school districts.

In 1864, curricular development for music education began to form. According to Mark (1989), Luther Whiting Mason went to Boston to do his pioneering work in extending the music program downward through the primary grades. The concern of music educators during this time was what should be the contribution of music to the lives of their students and how the music curriculum should support that contribution (Mark, 1989).

During this time, music began to be taught by classroom teachers with the assistance of music supervisors. As Mark (1989) indicated, Mason's instruction book series, National Music Method, was published in 1870, which was a structured approach to music reading. This led to the development of additional instruction books being created and training opportunities for teachers and music supervisors who wanted to learn how to use the new materials effectively. 
In the beginning of the twentieth century, more major curriculum developments were introduced. As Mark (1989) indicated, these curriculum developments included the introduction of harmony, rhythmic motion, voice training, and music appreciation. When developments of the phonograph and commercialization of radio became eminent in society, listening programs were created; this enabled the music program to help children become listeners as well as performers. Also during this time, as Mark (1989) indicated, school boards all across the country came to recognize the value and feasibility of music instruction, and music education began to be adopted as a curricular subject in numerous school districts.

In the 1920s, the notion of musical performance in the public schools began to expand as a new branch of music education. As Mark (1989) indicated, choral performance had been of importance for some time, but with the introduction of school bands and orchestras, a new emphasis on excellence in performance came into existence. This emphasis began the influence of the contest movement and school-performing ensembles became extremely visible to the public eye; they were often a source of pride to the communities from which they came (Mark, 1989).

Mark (1989) indicated that during this time period, the American public supported school music more strongly than before because the results were so tangible in the performing ensembles; "general music was also supported because of its central role in the progressive education philosophy that guided American education at that time" (p. 4). This time period created the notion of music performance assessments nationwide and in the State of Florida in particular, the Florida Bandmasters Association (FBA) created and implemented district and state music performance assessments (MPAs) in the 1940s. 
In the 1960s, Mark (1989) indicated: "the music education philosophical literature began to emphasize the need for programs and curricula based on the aesthetic aspect of music, rather than on extra-musical benefits of the study of music" (p. 5). During this time, the music education profession began to adopt a world-view and was used to help students relate to societies and cultures with which they were unfamiliar. Music instruction at this time was also beginning to be used to support and enrich other subjects taught in school.

These events prompted the present day advent of music education advocacy, which continues today to lead music educators to introspection about why music is important to children, communities and the nation, and to learn to articulate their beliefs (Mark, 1989). After the next section of this literature review, The Role of Middle School Education, a plethora of literature will be presented in the proceeding sections to support the assertions stated earlier in this paragraph.

\section{The Role of Middle School Education}

As this study sought to investigate the relationship between a middle school student's participation in the District Concert Band Music Performance Assessment and achievement on the Florida Standards Assessments (FSA), a concise history and purpose of middle school education is presented.

From West and Schwerdt's (2012) study, their results suggested: "school transitions [from elementary to middle or middle to high school] lower student achievement but that attending middle schools in particular has adverse consequences for American students" (p. 68). As test scores indicate, this is unfortunately the reality in middle schools across the country. Educators (teachers and administrators) are charged 
with the responsibility of devising pedagogical methods of ensuring that middle school students do not fall victim to a sharp decline in student achievement.

Manning (2000) stated that young adolescent learners (those in the current middle school age group) require school programs and practices that meet their unique developmental and educational needs. During the nineteenth century, the configuration for schooling was eight-year elementary and four-year high schools. As Manning (2000) pointed out, this configuration did not adequately address the educational and developmental needs of young adolescents.

During the beginning of the twentieth century, junior high schools were created to better serve the needs of young adolescents and these schools were comprised of students in Grades 7-9. As Manning (2000) indicated, these needs were enriched academic programs for college-bound students, vocational programs for students heading into the job market, and meeting the unique social, personal, and academic needs of young adolescents.

Manning (2000) points out that during the 1950s and 1960s, questions arose as to whether the junior high school actually served the needs and interests of young adolescents and the first middle school was established in 1950. It was proposed that the middle school build its programs on the positive contributions of the junior high school; that is, a core curriculum, guidance programs, exploratory education, and vocational and home arts (Alexander \& Williams, 1968; Manning, 2000).

This We Believe: Developmentally Responsive Middle Level Schools (1995) was a position paper created by the National Middle School Association and it sought to serve as a guide to assist in achieving developmentally responsive educational programs 
for young adolescents. The position paper asserted, "in order to be developmentally responsive, middle level schools must be grounded in the diverse characteristics and needs of these young people" (p. 10).

This We Believe (1995) asserted that a developmentally responsive middle level school shall provide a curriculum that is challenging, integrative, and exploratory. An instance of the aforementioned curriculum includes "those specific classes designed to advance academic skills and knowledge as well as school-wide services such as guidance, clubs and interest groups, music and drama productions, student government, and sports" (This We Believe, 1995, p. 24).

In addition to the core subjects, curriculum should also be exploratory in nature, especially on the middle school level. It enables students to discover their particular abilities, talents, interests, values, and preferences; this helps students to prepare for adult life, not only in terms of vocation, but also as family members and citizens (This We Believe, 1995). These experiences would acquaint students with enriching, healthy leisure-time pursuits, such as lifetime physical activities, involvement in the arts, and social service; this develops young adolescents into well-rounded adults (This We Believe, 1995).

The exploratory approach is also mentioned in Gilstrap (1994), in which he asserted, "the exploratory program has been identified as one of the most successful components [of the middle school]" (p. 252). Exploration is designed to afford students opportunities to discover their strengths, weaknesses, likes, dislikes, and potential future curriculum choices; one of the most difficult tasks middle level students encounter is understanding the person they are becoming (Compton \& Hawn, 1993; Gilstrap, 1994). 
These statements suggest that in addition to a rigorous core curriculum, middle school students in particular are in dire need of elective courses, such as vocational courses and music, and not affording them these choices in school would be a disservice to both their development in school and development as a human being to society.

\section{Theoretical Framework: Howard Gardner's Theory of Multiple Intelligences}

Howard Gardner developed the theory of multiple intelligences and he specializes in developmental psychology and neuropsychology. The development of his theory of multiple intelligences came into existence when he analyzed his own studies of the development and breakdown of cognitive and symbol-using capacities; he became convinced that Jean Piaget's view of intellect was flawed, which suggested that all aspects of symbol use was a part of a single "semiotic function" (Gardner \& Hatch, 1989).

Instead, Gardner and Hatch (1989) believed that empirical evidence was accruing that the human mind may be quite modular in design; separate psychological processes appear to be involved in dealing with linguistic, numerical, pictorial, gestural, and other kinds of symbolic systems. This theory supports the notion of educating the whole child and the importance of maximizing a child's potential.

An additional issue that led Howard Gardner to develop his theory of multiple intelligences was the fact that schools were stressing only two forms of symbol use, which are linguistic symbolization (reading) and logical-mathematical symbolization (mathematics). These two forms are used overwhelmingly in the construction of items on intelligence, aptitude, and achievement tests; Gardner believed that if different kinds of 
items were used, or different kinds of assessment instruments devised, a quite different view of the human intellect might issue forth (Gardner \& Hatch, 1989).

Gardner defines intelligence as the capacity to solve problems or to fashion products that are valued in one or more cultural settings (Gardner \& Hatch, 1989). The list of intelligences that Gardner created was derived from what he and his colleagues examined in the literature in several areas. Gardner and Hatch's (1989) examination of the literature included the development of cognitive capacities in normal individuals, the breakdown of cognitive capacities under various kinds of organic pathology, the existence of abilities in "special populations" (prodigies, autistic individuals, idiots, savants, and learning-disabled children), forms of intellect that exist in different species, the evolution of cognition across the millennia, and two forms of psychological evidence: the results of factor analytic studies of human cognitive capacities and the outcome of studies of transfer and generalization.

Especially in an urban school district, this wide variety of student learners does exist in the schools and this theory can infer the importance of utilizing different pedagogical methods to effectively educate all children. Diversity is also widespread in schools, especially in an urban school district, and as McFarlane (2011) stated:

We are living in a truly global society where diversity has become the most defining aspect of social life; this diversity is reflected in the $21^{\text {st }}$ century school and classroom where students from all walks of life (representing diverse languages, cultures, ethnicities, nationalities, religions, and socialization backgrounds — not to mention unique individual personalities) meet in a singular place where the instructor must be able to facilitate vast differences. (p. 8) 
Table 1 is taken from Gardner and Hatch (1989), which lists Howard Gardner's first seven intelligences from the theory of multiple intelligences:

Table 1

The Seven Intelligences

\begin{tabular}{|c|c|c|}
\hline Intelligence & End-States & Core Components \\
\hline Logical-mathematical & $\begin{array}{l}\text { Scientist } \\
\text { Mathematician }\end{array}$ & $\begin{array}{l}\text { Sensitivity to, and capacity to discern, } \\
\text { logical or numerical patterns; ability to } \\
\text { handle long chains of reasoning. }\end{array}$ \\
\hline Linguistic & $\begin{array}{l}\text { Poet } \\
\text { Journalist }\end{array}$ & $\begin{array}{l}\text { Sensitivity to the sounds, rhythms, and } \\
\text { meanings of words; sensitivity to the } \\
\text { different functions of language. }\end{array}$ \\
\hline Musical & $\begin{array}{l}\text { Composer } \\
\text { Violinist }\end{array}$ & $\begin{array}{l}\text { Abilities to produce and appreciate rhythm, } \\
\text { pitch, and timbre; appreciation of the forms } \\
\text { of musical expressiveness. }\end{array}$ \\
\hline Spatial & $\begin{array}{l}\text { Navigator } \\
\text { Sculptor }\end{array}$ & $\begin{array}{l}\text { Capacities to perceive the visual-spatial } \\
\text { world accurately and to perform } \\
\text { transformations on one's initial } \\
\text { perceptions. }\end{array}$ \\
\hline Bodily-kinesthetic & $\begin{array}{l}\text { Dancer } \\
\text { Athlete }\end{array}$ & $\begin{array}{l}\text { Abilities to control one's body movements } \\
\text { and to handle objects skillfully. }\end{array}$ \\
\hline Interpersonal & $\begin{array}{l}\text { Therapist } \\
\text { Salesman }\end{array}$ & $\begin{array}{l}\text { Capacities to discern and respond } \\
\text { appropriately to the moods, temperaments, } \\
\text { motivations, and desires of other people. }\end{array}$ \\
\hline Intrapersonal & $\begin{array}{l}\text { Person with } \\
\text { detailed, } \\
\text { accurate self- } \\
\text { knowledge }\end{array}$ & $\begin{array}{l}\text { Access to one's own feelings and the } \\
\text { ability to discriminate among them and } \\
\text { draw upon them to guide behavior; } \\
\text { knowledge of one's own strengths, } \\
\text { weaknesses, desires, and intelligences. }\end{array}$ \\
\hline
\end{tabular}


Since the publication of Gardner and Hatch (1989), Gardner added two additional intelligences to his theory, which brought the total number of intelligences in his theory to nine. Table 2, taken from McFarlane (2011), lists the two additional intelligences:

Table 2

Intelligences Eight and Nine of the Theory of Multiple Intelligences

\begin{tabular}{|c|c|}
\hline Intelligence & Description \\
\hline Naturalist & $\begin{array}{l}\text { Designates the human ability to discriminate among living things } \\
\text { (plants, animals) as well as sensitivity to other features of the natural } \\
\text { world (clouds, rock configurations). }\end{array}$ \\
\hline Existential & $\begin{array}{l}\text { Sensitivity and capacity to tackle deep questions about human } \\
\text { existence, such as the meaning of life, why do we die, and how did } \\
\text { we get here. }\end{array}$ \\
\hline
\end{tabular}

Gardner's theory of multiple intelligences suggests that standardized tests, as currently created, are limited because it exclusively stresses linguistic and logical skills. Gardner and Hatch (1989) suggests that the theory of multiple intelligences requires a fresh approach to assessment; the approach must be consistent with the view that there are a number of intelligences that are developed, and can be best detected in "culturally meaningful activities" (p. 6).

The theory of multiple intelligences was important to this study in two ways. First, this theory supports the notion of educating the whole child because, as the theory suggests, people learn in different ways and have varying abilities and intelligences; not just linguistic and logical skills, but also in many other areas such as musical, spatial, body-kinesthetic, interpersonal, and intrapersonal skills. Griggs, Barney, BrownSederberg, Collins, Keith, and Iannacci (2009) stated the notion: "as educators attempt to 
engage students in a variety of ways, knowing which intelligences students possess is critical to effective instruction...if instructors know the strengths of their students, they can better prepare engaging and relevant lessons that correlate with those strengths" (p.55).

Second, music is considered one of Howard Gardner's nine multiple intelligences. McFarlane (2011) suggests that according to Howard Gardner, musical intelligence runs in an almost structural parallel to linguistic intelligence, which deals with written language and its understanding (reading comprehension). Additionally, Gardner (2011) suggests that there is an affective connection between music and the emotions, and mathematical and musical intelligences may share common thinking processes.

As the preceding paragraph points out, there is research which suggests that music can be inferred as an intelligence to strengthen reading and mathematics achievement in school, and the proceeding section of this literature review will introduce literature that presents the benefits of music education to student achievement.

\section{The Benefits of Music Education to Student Achievement}

This section of the literature review presents a synthesis of the literature, which suggests that there are benefits and a positive relationship to music education and student achievement. This section will begin with one of the most prevalent empirical research studies conducted with the notion that "music makes you smarter": The Mozart Effect. Next, this section will also present literature, which suggests that there is a positive relationship between music education in school and reading and mathematics achievement. 


\section{The Mozart Effect}

The purpose of Demorest and Morrison's (2000) correlational study was to determine whether music makes a person smarter than someone who does not study music. Music teachers oftentimes use earlier research to say that students who study music are smarter than their other peers and Demorest and Morrison (2000) wrote this article to "carefully review some of the better-known studies examining potential relationships between music or music instruction and other areas of knowledge" (p. 33). This can be regarded as the authors' justification for conducting this study, since it was published in a national music education journal.

The research studied two methods of determining the correlational effect of music on an individual's "smartness:" The Mozart Effect and Keyboard Training. The Mozart Effect tested the students' ability to complete a single spatial reasoning task. It tested whether or not there would be a difference in the results between the groups of students that listened to Mozart 10 minutes prior to the test versus those that did not. The Keyboard Training project was twofold; the first study tested the spatial reasoning of students that received eight months of music training versus those that did not and the second study tested the spatial reasoning of students that received computer keyboard training versus a group that received only singing instruction. In the overall study, SAT scores were also compared to those students that took music in school versus those that did not.

In the Mozart Effect, 79 college students took a spatial reasoning test. The test was comprised of 16 exercises that the students had to solve in their minds the shape and design of a piece of paper that had been folded and cut. On the first day, they all took the 
test together but on days two through five they were divided into three groups. Before retaking the test, 26 students listened to ten minutes of silence, 27 of them listened to ten minutes of Mozart, and 26 students listened to ten minutes of a mix of minimalist music, dance music, and spoken text. As measured by the results of the spatial reasoning test, it was determined which group of students scored the best. Figure 1 below, taken from Demorest and Morrison (2000), shows an example of an exercise that was used in the spatial reasoning test:
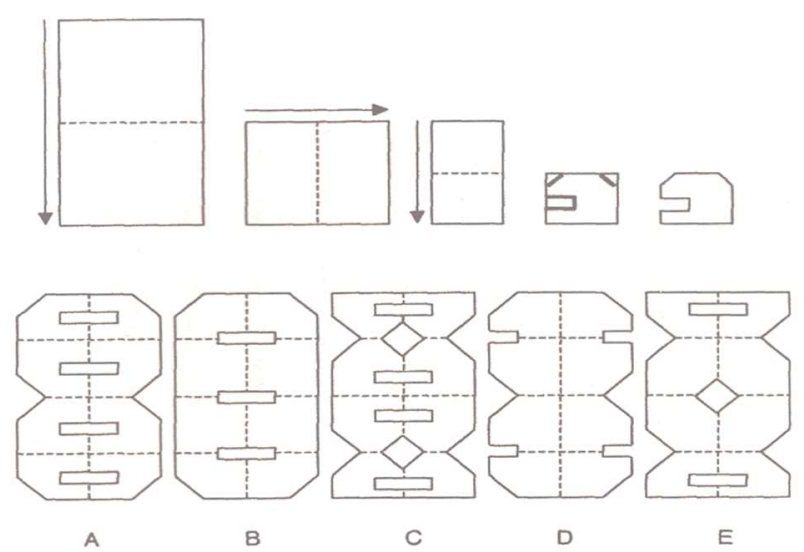

Figure 1. Example of the paper folding and cutting task used in the spatial reasoning test.

In the first study of the Keyboard Training project, Demorest and Morrison (2000) showed that 19 three and four-year olds received eight months of music training consisting of 30 minutes of singing daily and 10 to 15 minutes of keyboard a week, while 14 in the control group received no music instruction. After four months and then eight months, the scores of the test on spatial reasoning would determine whether or not the two different environments would show a difference in the students' results. 
In the second study of the Keyboard Training project, 34 three-year-olds received eight months of music training consisting of 30 minutes of singing daily and 10 to 15 minutes of piano keyboard instruction a week. Demorest and Morrison (2000) also showed that three other groups were divided into 20 students receiving computer keyboard lessons of the same length and number as the piano lessons, 10 students receiving only a half hour of daily singing, and 14 students receiving no music instruction and no computer training. Four tests would be given before and after the training; one of them assessing spatial-temporal reasoning and the other three, spatial recognition. Again, the scores of the spatial reasoning test would determine whether or not significant differences in scores would be evident.

The data collection method that the researchers used in both the Mozart Effect and the Keyboard Training experiments was an aptitude test. The aptitude test that was used for these two experiments was a single spatial reasoning test derived from a subtest of the Stanford Binet Intelligence Scale, thought by the authors to best represent spatialtemporal reasoning (Demorest \& Morrison, 2000).

The advantage of using an aptitude test as a data collection method for this experiment is that it measures the intelligence level of a student. The title of the article Does Music Make You Smarter suggest that it is trying to determine if music could make an individual "more smarter" or "intelligent," so this is why using an aptitude test for these studies was a good idea.

In both the Mozart Effect and Keyboard Training experiments, the scores from the spatial reasoning test were analyzed. In the Mozart effect, the scores of the reasoning test were compared with the students who listened to 10 minutes of Mozart, those who 
listened to 10 minutes of a mixture of minimalist music, dance music, and spoken text, and those who listened to 10 minutes of silence. In the first Keyboard Training experiment, the scores from the spatial reasoning test of 19 three and four-year olds who has 30 minutes of singing daily and 10 to 15 minutes of keyboard a week were compared to 14 children who did not receive music instruction. In the second Keyboard Training experiment, 20 children received computer keyboard lessons, 10 children received 30 minutes of daily singing instruction only, and 14 received no computer keyboard or music instruction. A pretest was given in all of these experiments before variables such as silence, music, or music instruction, were imposed on the students in order to determine whether or not music had an effect on the students' scores.

In the Mozart Effect, Demorest and Morrison (2000) reported that the group that listened to Mozart improved significantly from day one to day two and from day two to day three while the group that listened to silence also improved, but only from day two to day three. However, on a separate short-term memory test, Demorest and Morrison (2000) also reported that the presence of music made no difference at all.

In the first Keyboard Training experiment, Demorest and Morrison (2000) reported that the music group showed significant improvement on one of the five tasksobject assembly—and scored significantly higher than the nonmusic group. In the second Keyboard Training experiment, Demorest and Morrison (2000) reported that the music keyboard group showed significant improvement only on the spatial-temporal reasoning test. None of the other groups tested showed significant improvement on any of the tests. 
Demorest and Morrison (2000) presented a statistic and graph that students who study music and other arts during their precollege years scored significantly higher on both the verbal and the mathematics portions of the SAT. The scores are above the average for students overall and well above average for those students who did not participate in fine arts. However, the graph showed that their scores were not the highest; those who studied music scored lower than those students who were in acting and drama appreciation. Even more interesting, those who were enrolled in music appreciation scored higher than those in music performance. Looking at the results, they favor the belief that music study as a whole makes you smarter.

The researchers concluded with the mean SAT scores that interpreting the scores could suggest that music study plays an active role in raising levels of academic achievement. Another finding showed that the longer a student stayed in music, the greater the academic performance would improve. Furthermore, the researchers Demorest and Morrison (2000) believed that "to gain further insight into the relationship between music and academic achievement, we need to compare the scholastic progress of students over time; we might also consider the academic profile of students prior to their selection of a music elective" (p. 38).

Music could make you smarter in the area of spatial-temporal ability, which Gallagher (2008) defined as recognizing the relations between objects and mentally transforming them through space and over time without a physical representation. Gallagher (2008) also suggested that "such a relationship has implications for the role of music in such traditionally nonmusical fields as mathematics, architecture, engineering, and chess, in which spatial-temporal reasoning plays a large part because it incorporates 
many mathematical and scientific concepts, such as proportions and geometry" (paragraph 3). Demorest and Morrison (2000) gave the conclusion best by saying, "students who participate in music and the other arts tend to be the most academically successful” (p. 38).

\section{Student Achievement in Reading and Mathematics}

Standardized and high stakes testing has become the increased focus of today's public schools and educators are charged with the task and responsibility of helping students to be successful on these tests. There is a body of literature, which suggests that students who study music are more successful on these tests than those who do not. Wetter, Koerner, and Schwaninger's (2009) correlational study compared school performance of 53 children studying music with 67 children that were not studying

music. The average achievement scores of all school subjects were significantly higher in children who studied music than in those who did not study music. A slight decrease of the overall average achievement scores over a four-year period from students in Grades 3-6 was found in the control group only. There was a correlation between music training and better student performance.

Wetter, Koerner, and Schwaninger (2009) suggested that over time, continuous musical training emerges to help achieve and maintain school performance at a high level. This correlational study suggests the notion that students who are involved in music in school have better performance marks at school. It can also infer the notion that the longer a student is involved in music, the higher their scores would increase over time. 
Across the United States, perhaps the lowest average standardized scores from students in Grades K-12 are in reading. One of the first skills that students learn in school is their ABCs, which is taught via the concept of phonemic awareness. Phonemic awareness is the ability to recognize that a spoken word consists of individual sounds or phonemes and it is one of the best predictors of how well children will learn to read (Ehri, Nunes, Willows, Schuster, Yaghoub-Zadeh, \& Shanahan, 2001; Gromko, 2005). The ability to read and write with understanding enhances children's interpersonal communication, expands their worlds, and leads to independence in learning; therefore, it is not surprising that literacy and reading comprehension are issues of national concern (Gromko, 2005).

Gromko's (2005) correlational study focused on the notion that music instruction was related to significant gains in the development of young children's phonemic awareness, particularly in their phoneme-segmentation fluency. The data from the study showed that the kindergarten children who received the music instruction showed significantly greater gains in the development of their phoneme segmentation fluency than those kindergarten children who did not receive the music instruction. Gromko (2005) made the assertion that "active music-making and the association of sound with developmentally appropriate symbols may develop cognitive processes similar to those needed for segmentation of a spoken word into its phonemes" (p. 199). This study may suggest that music instruction is an important component of a young child's education because of the notion that music can enhance a child's phonemic awareness development early on in life, which could help reduce the number of students struggling with reading skills. 
Schon, Boyer, Moreno, Besson, Peretz, and Kolinsky (2008) have shown in previous research that "adults and infants can use the statistical properties of syllable sequences to extract words from continuous speech and that a similar learning technique operates with musical stimuli” (p. 976). In their correlational study, they combined musical and linguistic information and compared language learning based on speech sequences to language learning based on sung sequences. The results showed a strong learning boost of song compared to speech. Most importantly, learning a new language, especially in the first learning phase where the segmentation of new words is learned, may largely benefit of the structuring and motivational properties of music in song. Cooper (2010) suggested that songs and stories have a heavy correlation with one another and have the ability to increase brain development, increase vocabulary, and advance academic achievement. It also suggested that the sounds and fundamental structures of reading and singing provide young children with successful ways to increase memory, advance language skills, and promote literacy. Brain imaging provides researchers and teachers with evidence the songs and stories can "light up the brain" (Cooper, 2010, p. 24). Studies have shown that infants who received systematic prenatal musical stimulation exhibit remarkable attention behaviors, imitate accurately sounds made by adults (including nonfamily members), and appear to structure vocalization much earlier than infants who did not have prenatal musical stimulation (Cooper, 2010; Shetler, 1985).

Register et al. (2007) points out that music has influence on children's acquisition and mastery of literacy skills. They implemented a correlational study to create a shortterm music curriculum that was designed to improve reading comprehension and 
vocabulary in order to evaluate its effectiveness. The study was implemented using second-grade students and students who were identified as having a specific learning disability (SLD) in reading. The study revealed that students with a specific learning disability in reading improved significantly in word decoding, word knowledge, and reading comprehension. It also revealed that the second-grade students without a SLD showed a significant improvement in word decoding and word knowledge.

Register et al. (2007) provides the fact that literacy acquisition and learning is a primary focus among educators. The SLD category has the greatest incidence of any of the special education areas and is the designation for funding and remediation of reading problems (Foorman et al., 1997; Register et al., 2007). As educators are becoming increasingly accountable for the successful achievement of students with a SLD on standardized testing, these aforementioned results could infer that music instruction can be infused in the total curriculum to assist these students in improving their reading skills.

Speaking of students with special needs, Summa-Chadwick (2009) showed that discoveries about how the body physiologically responds to music have opened new possibilities to aid in the learning processes of children with special needs. The procedures actively engage the brain by using rhythmic entrainment. These procedures can have positive outcomes when actively treating issues related to motor, speech/language, and cognition. Summa-Chadwick (2009) also mentioned that music and the temporal structure can evoke consistent response in the body and can therefore be used to intentionally direct therapeutic changes.

Summa-Chadwick's (2009) article presented techniques and protocols used in therapy sessions that are described as rhythmic entrainment for therapeutic purposes and 
were developed and researched at the Center for Biomedical Research in Music (CBRM) at Colorado State University; they are defined as "techniques, which utilized the therapeutic application of music to cognitive, sensory, and motor dysfunction due to neurological disorder or disease" (p. 39). All protocols were based on a neuroscience model of music perception and the influence of music on functional changes in nonmusical brain and behavior functions.

In addition to the notion that music contributes to the improvement of reading achievement in students, there is also research, which suggests that music also enhances mathematics achievement as well. The connection between music and cognitive benefits, especially in mathematics skills, is generally traced to the ancient Greek, Pythagoras, who in the fifth century BCE suggested that mathematical relationships were integral to physical properties, including music (Southgate \& Roscigno, 2009).

Emergent mathematics is a concept that describes how children begin to construct mathematics from birth and continue throughout their lives; this knowledge is built through a combination of cognitive development and interaction with their environment (Geist \& Geist, 2008). Music is mathematical in nature; it deals with the concepts of steady beat, rhythm, tempo, volume, melody, and harmony. These concepts are introduced and exposed to young children when they are taught nursery rhymes in preschool.

As Geist and Geist (2008) points out, early childhood educators can use simple musical elements to introduce mathematical concepts, interactions, and ideas to infants, toddlers, and preschoolers; even babies are constructing the foundations of mathematics (Butterworth, 2005; Geist \& Geist, 2008). If teachers recognize and use the 
aforementioned musical concepts, they can learn to use them to foster young children's early mathematical thinking (Geist \& Geist, 2008). By fostering and enhancing these skills early on, these students would be more likely to become stronger students in mathematics throughout their schooling — from preschool age throughout high school and beyond.

University programs in mathematics education and public schools are joining in projects to address the problems of context, discourse, and community that arise when trying to teach K-8 mathematics to at-risk children (Bryan \& Dorrington, 2004). At-risk children are generally the ones that tend to struggle with mathematics in school, as compared to those of higher socioeconomics. As Bryan and Dorrington (2004) points out, "these partnerships will bring about a deeper understanding of the interplay of language, culture, and mathematics education, and thereby enhance the mathematics achievement of all students, including ethnic minority children and at-risk students" (p. 7).

Bryan and Dorrington (2004) listed different ways that educators can create a culture of understanding and relevancy of mathematics in the students' lives. One of the ways that the authors listed was utilizing music to help mathematics to cross cultural and socioeconomic boundaries. Standard musical notation uses such symbols as half-notes, quarter-notes, and eighth-notes to represent duration of sound (Bryan \& Dorrington, 2004) and having students chant and clap notated musical rhythms is an engaging way to explore the adding and subtracting of fractions, as well as other relationships (Bryan \& Dorrington, 2004; Woody, 1998). As the authors suggest, using music in the 
mathematics classroom can also grasp the students' attention and in the process, can help them to learn mathematical skills.

\section{Attendance, Graduation, and Social Skills}

Music Makes the Grade (2007) showed that out of the principals and vice principals interviewed, whom were randomly selected from public schools across the country, $96 \%$ of them agreed that participating in music education encourages and motivates students to stay in school. Furthermore, $89 \%$ of those principals felt that a high-quality music education program contributes to their school achieving higher graduation rates.

Additional correlational data from Music Makes the Grade (2007) indicated schools that have music programs have significantly higher graduation rates $(90.2 \%)$ than those without music programs (72.9\%). The quality of the school's music program also had a significant impact on its graduation rate; those that rated their program as “excellent or very good” had an even higher graduation rate, at 90.9\%.

Music Makes the Grade (2007) also indicated schools that have music programs have significantly higher attendance rates $(93.3 \%)$ than those without music programs $(84.9 \%)$. This connection of graduation and attendance rates matches a current emphasis placed on education by the public and by the law... according to the No Child Left Behind Act of 2000, section 9101, the arts are classified as a "core academic subject;" that in itself is recognition of the inherent value of the study of music (Music Makes the Grade, 2007).

Olson (2009) presented the results of a correlational study conducted by Whitworth University music professor Richard Strauch, which assessed the freshman 
class for Whitworth's 2007-2008 academic year. Strauch found that Whitworth students who stuck with their high school music program (in which the majority of these students started in a music program while in elementary or middle school) had higher GPAs and standardized test scores upon entering the university than Whitworth's general freshman class, and that students who continued their involvement in music remained academically above average.

In addition to attendance and graduation, K-12 schools are also charged with the responsibility of preparing the nation's students for society. Youth music participation is associated with higher matriculation rates, higher rates of acceptance into medical schools, lower rates of current and lifetime alcohol, tobacco, or drug abuse, and lower rates of disruptive classroom behaviors (Aschaffenburg \& Maas, 1997; National Center for Educational Statistics, 1997; Southgate \& Roscigno, 2009; Texas Commission on Drug and Alcohol Abuse, 1999; Thomas, 1994).

One of the most important skills that one must acquire to survive in society is social skills. Gooding (2009) suggested that strong social skills are vital for successful functioning in life. Social skills can affect academic success, peer relationships, family relationships, employment, and extracurricular and leisure activities. Children and adolescents who display academic, social, and behavioral deficits are at risk for both short-term and long-term negative social and academic outcomes.

Because of disability-specific deficits that lead to fewer interactions with peers and/or difficulty establishing meaningful relationships, children with disabilities are at a much greater risk for demonstrating poor social skills. Gooding (2009) asserted, “children need opportunities to learn social skills, practice those skills, and receive 
corrective feedback about their performance of those skills" (p. 35). Because music is an inherently social activity, the music classroom is an ideal place to help students develop or improve vital social skills.

When looking at the specific social skills necessary for success in the classroom setting, Gooding (2009) presented three primary skill areas: (a) skills that help children relate to others (interpersonal behaviors); (b) skills that help children regulate themselves (self-related behaviors); and (c) skills that help children complete assigned tasks (taskrelated behaviors). These three aforementioned skill areas are consistently taught within the band room context through its daily activities. Gooding (2009) also presented a general social skills table, which takes these three primary skill areas and provides specific skills under each area. In addition, it provides concrete behaviors that demonstrate each skill. Table 3 is taken from Gooding (2009): 
Table 3

General Social Skills

\begin{tabular}{|c|c|c|}
\hline Skill Area & Specific Skill & Example Behavior \\
\hline \multirow{10}{*}{ Interpersonal behaviors } & Accepting authority & To know and follow classroom rules \\
\hline & Coping with conflict & To walk away from a peer when angry \\
\hline & Gaining attention & To use please and thank you \\
\hline & Greeting others & To make eye contact when greeting others \\
\hline & Helping others & To help a peer when asked \\
\hline & Making conversation & To wait for pauses before speaking \\
\hline & Organized play & To follow rules during a game \\
\hline & Positive attitude toward others & To compliment others \\
\hline & Playing informally & To share \\
\hline & Property: own and others & To ask permission to use others' property \\
\hline \multirow[t]{6}{*}{ Self-related behaviors } & Accepting consequences & To apologize \\
\hline & Ethical behavior & To answer truthfully \\
\hline & Expressing feelings & To verbally describe own feelings \\
\hline & Positive attitude toward self & To make positive statements about self \\
\hline & Responsible behavior & To arrive on time \\
\hline & Self-care & To keep clean \\
\hline \multirow[t]{10}{*}{ Task-related behaviors } & Asking and answering questions & To ask appropriate questions for info \\
\hline & Attending behavior & To look at someone speaking \\
\hline & Classroom discussion & To use appropriate tone of voice \\
\hline & Completing tasks & To complete and return assignments \\
\hline & Following directions & To follow verbal directions \\
\hline & Activities & To share \\
\hline & Independent work & To find acceptable use of free time \\
\hline & On-task behavior & To work steadily for required time \\
\hline & Performing before others & To read aloud/to perform in front of peers \\
\hline & Quality of work & To turn in neat papers \\
\hline
\end{tabular}

\section{Educating the Whole Child}

Public schools in the United States were established as much for moral and social reasons as for academic instruction (Noddings, 2005). Jefferson (1818) included in his 
report that the objectives of education, in addition to reading, writing, and arithmetic, should include qualities such as morals, the understanding of duties to neighbors and country, knowledge of rights, and intelligence and faithfulness in social relations. Noddings (2005) stated: "we should demand more from our schools than to educate people to be proficient in reading and mathematics...too many highly proficient people commit fraud, pursue paths to success marked by greed, and care little about how their actions affect the lives of others" (p. 10).

These notions introduce the concept of educating the whole child. The National Education Association listed seven aims of education in its Cardinal Principles of Secondary Education report in 1918: (a) health; (b) command of the fundamental processes; (c) worthy home membership; (d) vocation; (e) citizenship; (f) worthy use of leisure; and (g) ethical character (Kliebard, 1995; Noddings, 2005). From there, educators advocated for open education, which aimed to encourage creativity, invention, cooperation, and democratic participation in the classroom and in lifelong learning (Noddings, 2005; Silberman, 1973).

Noddings (2003) also suggested happiness as an additional aim of education; great thinkers have associated happiness with such qualities as a rich intellectual life, rewarding human relationships, love of home and place, sound character, good parenting, spirituality, and a job that one loves (Noddings, 2005). The aim of happiness is incorporated into education by helping our students understand the components of happiness and by making classrooms genuinely happy places (Noddings, 2005). Noddings (2005) suggests that these aims of education remind us: "students are whole persons - not mere collections of attributes" (p. 10). Schools must be concerned with the 
total development of children; schools as well as other social institutions share responsibility for nurturing the whole child (Noddings, 2005).

Noddings (2005) mentions how schools are supposed to be designed to serve both the individual and the larger society as a whole; society needs more than just competent workers in the workplace. It [society] wants graduates who exhibit sound character, have a social conscience, think critically, are willing to make commitments, and are aware of global problems (Noddings, 2005; Soder, Goodlad, \& McMannon, 2001). The authors suggest that schools which only focus on standardized test scores in reading and mathematics do not effectively foster the whole child.

Ediger (2006) presents the notion that in the humanism philosophy of education, education should reflect all of life's relevant endeavors and it should fulfill the needs of the individual. "Educating a part of the individual is not adequate, but should educate the total [whole] child" (Ediger, 2006, p. 180). Even though test scores measure a few areas, such as reading and mathematics, this limits the possibility of being able to educate the whole child (Ediger, 2006). In the current educational configuration in relation to grade promotion, the gifted, talented, and mentally impaired must achieve the same level of accomplishment to be promoted from one grade level to the next (Ediger, 2006).

Noddings (2005) stated how children are moral beings that must be provided with character education programs and are artistically inclined that must be provided arts classes, such as music. Wealthier students are enjoying a rich and varied curriculum and many opportunities to engage in the arts, whereas many of our less wealthy students spend their school days bent over worksheets in an effort to boost standardized test scores (Meier \& Wood, 2004; Noddings, 2005). Students have diverse talents, skills, and 
abilities, and these things need to be recognized and provided for in the classroom (Ediger, 2006).

The notion of educating the whole child serves as a summary of the whole aim of this study. This study was designed to support the notion of the positive relationship between music study in school and standardized achievement. As previously stated by Noddings (2005) and Ediger (2006), education is designed to be more than just preparing students to take and pass standardized tests; education is designed and charged with the responsibility of preparing our future citizens for society. 


\section{CHAPTER III}

\section{RESEARCH DESIGN AND METHODOLOGY}

This correlational study was designed to provide new, additional quantitative data to investigate the importance and usefulness of music education within the Miami-Dade County Public Schools curriculum. No quantitative research has been conducted involving the link between a middle-school student's District Concert Band Music Performance Assessment participation and Florida Standards Assessments (FSA) achievement scores by either the Florida School Music Association (FSMA) or MiamiDade County Public Schools, which is currently the nation's fourth largest school district.

\section{Research Questions and Hypotheses}

To identify any links between a middle school student's participation in the District Concert Band Music Performance Assessment (MPA) and Florida Standards Assessments (FSA) achievement on the English language arts (ELA) and mathematics subtests, an independent-samples $t$-test of the data was conducted to test the following research questions:

Research Question 1: Is there a statistically significant difference in ELA and mathematics achievement scores of middle school students in Miami-Dade County Public Schools who participated in the 2016 District Concert Band MPA and those who did not?

Research Hypothesis 1: There is a statistically significant difference between a middle school student's District Concert Band MPA participation and ELA and mathematics achievement scores. 
Research Question 2: For the middle school students who did participate in the District Concert Band MPA, is there a statistically significant difference between ELA and mathematics achievement scores and the level of music performed?

Research Hypothesis 2: There is a statistically significant difference between the students' ELA and mathematics achievement scores and the level of music performed by their respective band.

Research Question 3: For the middle school students that did participate in the District Concert Band MPA, is there a statistically significant difference between ELA and mathematics achievement scores and their band's overall rating received?

Research Hypothesis 3: There is a statistically significant difference between the students' ELA and mathematics achievement scores and their band's overall rating received.

\section{Research Design}

The study utilized a non-experimental ex post facto research design, which included descriptive, inferential, and predictive statistics. The data collection sources used for this study utilized information from the Miami-Dade County Public School's Student Performance Indicators (SPI) computer program. The SPI computer program contained the data of the students' achievement scores from the ELA and mathematics subtests of the 2016 Florida Standards Assessments (FSA) administration from the four Miami-Dade County Public Middle Schools that the study focused upon. The SPI computer program was only accessible by the respective school's principal.

The data collected was from the 2015-2016 school year. Four Miami-Dade County Public middle schools were selected for the study. Two of the middle schools 
were high-achieving schools with an active, established band program and the other two schools were low-achieving schools with an active, established band program. A highachieving school is defined as a school that is consistently designated as Grade A or B by the State of Florida Department of Education for at least the past two consecutive school years (2013-2014, 2014-2015 school year). A low-achieving school is defined as a school that is consistently designated as Grade C, D, or F by the State of Florida Department of Education for at least the past two consecutive school years (2013-2014, 2014-2015 school year). The students' achievement scores on the ELA and mathematics subtests of the FSA from each of the four schools were analyzed. For the FSA, the scores that the students can receive is divided into five achievement levels, where Level 1 is the lowest and Level 5 is the highest. A student receiving a passing score on a subtest is one that scores a minimum of a Level 3.

Additional data collection that was used for this study was retrieved from the Florida School Music Association website database, which contained the list of the middle schools that participated in the District Concert Band Music Performance Assessment for the 2015-2016 school year. Additionally, the database contained both the level of music played and the bands' final overall rating received at the music performance assessment.

\section{Population and Sample}

Four Miami-Dade County Public Middle Schools were randomly selected for this study. All four of the schools were traditional feeder pattern schools with the typical $6^{\text {th }}$ $8^{\text {th }}$ grade configuration and they also had a band that participated in the 2016 Concert Band MPA. For comparison purposes, Schools 1 and 2 were high-achieving middle 
schools with an active, established band program. On the other hand, Schools 3 and 4 were low-achieving middle schools with an active, established band program.

From the four schools, the ELA and mathematics achievement scores of all the middle school students that participated in the 2016 District Concert Band Music Performance Assessment were used in this study. Additionally, a stratified random sampling was conducted of the students from each of the four schools that are not in the band program, in which they did not participate in the District Concert Band MPA. The reason for the stratified random sampling of the students that are not in the school's band program was because the researcher wanted to stratify the nonparticipants by grade level. It was ideal that for each of the four schools, the number of sixth, seventh, and eighth graders from the sample of students that were not in the band program matched the same number of sixth, seventh, and eighth graders that participated in the District Concert Band MPA.

\section{Research Variables}

The following variables were used to test the three research hypotheses, which sought to investigate the link between a middle school student's District Concert Band Music Performance Assessment participation and the effect on the student's ELA and mathematics achievement scores:

\section{Predictor Variables}

The predictor variables that were used in this study are: (a) a middle school student's District Concert Band Music Performance Assessment Participation versus nonparticipation, (b) a band's overall rating, and (c) level of music performed. 


\section{A middle school student's District Concert Band Music Performance}

Assessment Participation versus nonparticipation. This indicator variable was identified via the four middle schools' respective band director. This nominal variable was labeled whereas a 0 indicated a middle school student's nonparticipation and a 1 indicated a middle school student's participation in the District Concert Band MPA. All of the students that participated in the Concert Band MPA from the study's four schools were used in the study. As mentioned previously, the students that did not participate in the District Concert Band MPA were selected via stratified random sampling so that all grade levels are equally represented for each of the four middle schools.

Also known as the District Concert Band MPA, the District Concert Band Music Performance Assessment is the yearly performance assessment that takes place in the spring for each school district throughout the State of Florida. All active middle school bands throughout the district participate in this yearly assessment. The purpose of the MPA is to rate a band's performance on three prepared pieces of music and the band's sightreading ability as a whole.

For the performance of the prepared pieces, three adjudicators, certified by the Florida Bandmasters Association (FBA) and the Florida School Music Association (FSMA), rate the band's performance and a separate adjudicator rates the band's sightreading attempt on two unknown pieces of music. For adjudicators to be certified by the FBA and the FSMA, a grade K-12 band director's band must have received an overall Superior rating at least three out of the past five consecutive yearly District Concert Band MPA events; an adjudicator can also be a current college band director. All adjudicators 
must also participate in an adjudicator training to receive initial certification and must renew their certification every five years via a recertification training.

The ratings are averaged together to give the band a final rating: Superior, Excellent, Good, Fair, Poor; this is equivalent to receiving a letter grade of A, B, C, D, F, respectively. Note that the District Concert Band MPA is not a competition; it assesses each band's performance individually and it is possible (and typical) for several bands to receive an overall superior rating during the same assessment.

A band's overall rating. This variable was identified via the online database from the Florida School Music Association's (FSMA) Music Performance Assessment (MPA) database (n.d.). The database contained the overall rating for each middle school within the Miami-Dade County Public School system that participated in the District Concert Band Music Performance Assessment (MPA) for the 2015-2016 school year.

The band's overall rating refers to the final rating that each band receives from the District Concert Band Music Performance Assessment (MPA). The final rating is derived from the average of three adjudicators' ratings of the band's performance of the three prepared pieces of music and one adjudicator's rating of the band's sightreading attempt. Each of the four adjudicators can issue one of the five following ratings for a band's performance:

I. Superior (S): Equivalent to the letter grade of "A"

II. Excellent (E): Equivalent to the letter grade of "B"

III. Good $(\mathrm{G})$ : Equivalent to the letter grade of "C"

IV. Fair (F): Equivalent to the letter grade of "D"

V. Poor (P): Equivalent to the letter grade of "F" 
The ratings are derived from the adjudicators utilizing a Concert Band (and Sightreading) adjudicator's comment sheet, provided and approved by the Florida Bandmasters Association (FBA). A sample of the adjudicator's comment sheets that the adjudicators use for MPAs can be found in Appendix A. The adjudicator comment sheets contain fundamental musical concepts that a band program should exhibit during a performance; these musical concepts are taught in the music classroom by the band director on a daily basis.

Three of the adjudicators rate the band's performance on stage from the literature that the band rehearsed and prepared for the assessment. The fourth adjudicator assesses each band's sightreading abilities. Sightreading is the concept where a band sees an unknown piece of music for the first time, and after studying the piece of music with the band director for three minutes for the first piece and five minutes for the second piece (they are not allowed to play their instruments while studying each piece), the band is expected to perform the unrehearsed piece of music nonstop from beginning to end. Sightreading assesses a band's ability to perform an unrehearsed piece of music while incorporating the different musical elements listed on the adjudicator's comment sheet and with as few mistakes as possible.

Figures 2 and 3, taken from the Florida Bandmasters Association's Handbook, show how each combination of ratings yield the band's overall (final) rating: 


\begin{tabular}{|c|c|c|c|c|}
\hline $\begin{array}{c}\text { To Receive A } \\
\text { Superior }\end{array}$ & $\begin{array}{c}\text { To Receive An } \\
\text { Excellent }\end{array}$ & $\begin{array}{c}\text { To Receive A } \\
\text { Good }\end{array}$ & $\begin{array}{c}\text { To Receive A } \\
\text { Fair }\end{array}$ & $\begin{array}{c}\text { To Receive A } \\
\text { Poor }\end{array}$ \\
\hline S S S & S E E & S G G & S F F & S P P \\
\hline S S E & S E G & S G F & S F P & E P P \\
\hline S S G & S E F & S G P & E F F & G P P \\
\hline S S F & S E P & E G G & E F P & F P P \\
\hline S S P & E E E & E G F & G F F & P P P \\
\hline & E E G & E G P & G F P & \\
\hline & E E F & G G G & F F F & \\
\hline & E E P & G G F & F F P & \\
\hline & & G G P & & \\
\hline
\end{tabular}

Figure 2. The possible combinations of the ratings of the three adjudicators from the prepared pieces performance.

\begin{tabular}{|l|l|l|l|l|}
\hline $\begin{array}{c}\text { Final Rating of } \\
\text { Superior }\end{array}$ & $\begin{array}{l}\text { Final Rating of } \\
\text { Excellent }\end{array}$ & $\begin{array}{l}\text { Final Rating of } \\
\text { Good }\end{array}$ & $\begin{array}{l}\text { Final Rating of } \\
\text { Fair }\end{array}$ & $\begin{array}{l}\text { Final Rating of } \\
\text { Poor }\end{array}$ \\
\hline $\begin{array}{l}\text { Prepared Music: S } \\
\text { Sightreading: S }\end{array}$ & $\begin{array}{l}\text { Prepared Music: S } \\
\text { Sightreading: G }\end{array}$ & $\begin{array}{l}\text { Prepared Music: E } \\
\text { Sightreading: F }\end{array}$ & $\begin{array}{l}\text { Prepared Music: G } \\
\text { Sightreading: P }\end{array}$ & $\begin{array}{l}\text { Prepared Music: P } \\
\text { Sightreading: F }\end{array}$ \\
\hline Prepared Music: S & Prepared Music: S & Prepared Music: E & Prepared Music: F \\
Sightreading: E & Sightreading: F & Sightreading: P & Sightreading: G & Sightreading: G \\
\hline & Prepared Music: S & $\begin{array}{l}\text { Prepared Music: G } \\
\text { Sightreading: E }\end{array}$ & $\begin{array}{l}\text { Prepared Music: F } \\
\text { Sightreading: F }\end{array}$ & \\
& Sightreading: P & Prepared Music: E & Prepared Music: G & Prepared Music: F \\
& Sightreading: S & Sightreading: G & Sightreading: P & \\
\hline & Prepared Music: E & Prepared Music: G & Prepared Music: P \\
& Sightreading: E & Sightreading: F & Sightreading: S & \\
\hline & Prepared Music: E & Prepared Music: F & Prepared Music: P & \\
& Sightreading: G & Sightreading: S & Sightreading: E & \\
\hline & Prepared Music: G & Prepared Music: F & Prepared Music: P \\
& Sightreading: S & Sightreading: E & Sightreading: G & \\
\hline
\end{tabular}

Figure 3. The derivation of the band's overall (final) rating: averaging of a band's prepared pieces rating received from Figure 2 and the sightreading rating. 
Level of music performed. This variable was identified by utilizing the online database from the Florida School Music Association (FSMA) website as well as the online database from the Florida Bandmasters Association website. The databases contain the level of music that each middle school band performed at the District Concert Band Music Performance Assessment (MPA) during the 2015-2016 school year.

The bands prepare three pieces to perform on stage at the assessment. The first piece that the band performs is a "march-style" selection, which is chosen at the band director's discretion. The other two pieces that each band performs is chosen from an official list of pieces that is provided to each band director via the Florida Bandmasters Association (FBA). The pieces are ranked by Grade: it ranges from Grade I to Grade VI. Pieces of music that are ranked Grades IV to VI are typically performed at the high school assessment via high school bands.

Table 4, taken from the FBA Handbook, shows the minimum level of music that each middle school band must perform at the assessment:

Table 4

Classification Level Based on Seventh and Eighth Grade School Enrollment

\begin{tabular}{ccccccccc}
\hline Classification & $\begin{array}{c}\text { Seventh- } \\
\text { Eighth } \\
\text { Grade } \\
\text { Enrollment }\end{array}$ & $\begin{array}{c}\text { Grade } \\
\text { I }\end{array}$ & $\begin{array}{c}\text { Grade } \\
\text { II }\end{array}$ & $\begin{array}{c}\text { Grade } \\
\text { III }\end{array}$ & $\begin{array}{c}\text { Grade } \\
\text { IV }\end{array}$ & $\begin{array}{c}\text { Grade } \\
\text { V }\end{array}$ & $\begin{array}{c}\text { Grade } \\
\text { VI }\end{array}$ & $\begin{array}{c}\text { Sightreading } \\
\text { Music Class }\end{array}$ \\
MB & $701 \&$ Up & N/A & 2 & 0 & 0 & 0 & 0 & MB \\
MC & $1-700$ & 1 & 1 & 0 & 0 & 0 & 0 & MC \\
MD & New & 2 & 0 & 0 & 0 & 0 & 0 & MD \\
& School & & & & & & &
\end{tabular}

Note. 0 Indicates optional music level performance allowed 
For example, Table 4 above shows that a school with an MB classification must perform two Grade II pieces of music at the assessment (indicated by 2 in the Grade II column). The 0 in the Grade III-VI columns indicate that the band can optionally perform pieces of music in those Grades (music difficulty levels) in lieu of the required Grades.

\section{Criterion Variables}

The criterion variables that were used for this study are: (a) Florida Standards Assessments (FSA) English language arts (ELA) achievement scores for Grades 6, 7, and 8 collectively, and (b) Florida Standards Assessments (FSA) mathematics achievement scores for Grades 6, 7, and 8 collectively. Each year, the ELA and mathematics subtests of the Florida Standards Assessments (FSA) are required by the Florida Department of Education to be administered to all middle school students within Florida's public schools.

\section{Florida Standards Assessments (FSA) English language arts achievement}

scores. The ELA achievement scores of sixth, seventh, and eighth grade students of the two groups from each of the four middle schools in this study during the 2015-2016 school year, were retrieved from the Miami-Dade County Public Schools' SPI computer program. Group 1 from each of the four middle schools contained all of those students that participated in the District Concert Band MPA. Group 2 from each of the four middle schools contained all of those students who were sampled from the rest of the school's population that did not participate in the Concert Band MPA. A student receiving a passing score is one that scores a minimum of a Level 3 on the ELA subtest.

Florida Standards Assessments (FSA) mathematics achievement scores. The mathematics achievement scores of sixth, seventh, and eighth grade students of the two 
groups from each of the four middle schools in this study during the 2015-2016 school year, was retrieved from the Miami-Dade County Public Schools' SPI computer program. Group 1 from each of the four middle schools contained all of those students that participated in the District Concert Band MPA. Group 2 from each of the four middle schools contained all of those students who were sampled from the rest of the school's population that did not participate in the Concert Band MPA. A student receiving a passing score is one that scores a minimum of a Level 3 on the mathematics subtest.

\section{Procedures}

The first step in carrying out the study was to receive approval of the study from both the Institutional Review Board at Florida International University and the Research Review Committee for the Miami-Dade County Public Schools' Office of Evaluation and Research. After receiving approval from both the Institutional Review Board at Florida International University and the Research Review Committee for the Miami-Dade County Public Schools' Office of Evaluation and Research, data collection began.

Data were first collected from the Florida School Music Association's (FSMA) online database to identify which Miami-Dade County Public Middle Schools participated in the District Concert Band Music Performance Assessment (MPA) for the 2015-2016 school year. This online database is public records; anyone with a computer and an internet connection can access this information. After these data were collected, two groups of two middle schools were created. Group 1 consisted of two highachieving middle schools that have an active, established band program. Group 2 consisted of two low-performing middle schools that have an active, established band program. For both groups, one school was randomly selected from the northern half of 
the school district and the other school was randomly selected from the southern half of the school district. The north-south random selection was a function of the differing socioeconomic statuses (SES) of the school district. The southern part of the district tends to be a higher SES, while schools in the northern part of the district tend to be lower SES.

A high-achieving middle school is classified as a school that has been consistently ranked as an A or B school by the State of Florida Department of Education for at least the past two consecutive school years (2013-2014, 2014-2015 school year). A lowachieving middle school is classified as a school that has been consistently ranked as a $\mathrm{C}$, D, or F school by the State of Florida Department of Education for at least the past two consecutive school years (2013-2014, 2014-2015 school year). These letter grades are largely based on the schools' achievement scores as a whole via the state's standardized tests.

Data were also collected from the Miami-Dade County Public Schools' SPI computer program to identify the achievement scores of each six, seventh, and eighth grader that were used for this study. The achievement scores for both the 2015-2016 ELA and mathematics subtests was retrieved for each student. The overall sample was broken into two groups of students. Group 1 included those students that participated in the 2015-2016 Concert Band MPA from the four schools. These students were identified via the four middle schools' respective band director. Group 2 included those nonparticipating students that were selected for each of the four schools via stratified random sampling; one per ten students from the respective school's master list of students were randomly selected. The purpose of the stratified random sampling of the 
nonparticipating students was to stratify the nonparticipants by grade level. It is ideal that for each of the four schools, the number of sixth, seventh, and eighth graders from the sample of students that were not in the band program matched the same number of sixth, seventh, and eighth graders that participated in the District Concert Band MPA.

The mean ELA and mathematics achievement scores, comparing those students who were band members versus those who were not, tested the first hypothesis. The hypothesis was tested by comparing the means within each school as well as examining high performing versus low performing school means; the high performing versus low performing school analysis was a function of the differing socioeconomic statuses (SES) of the school district.

For the second and third hypotheses, a more in-depth relationship focused on those middle school students that did participate in the District Concert Band MPA for the 2015-2016 school year. The second hypothesis focused on whether there was a statistically significant difference between the middle school students' achievement scores for the ELA and mathematics examinations and the level of music that each student's band performed at the District Concert Band MPA for the 2015-2016 school year.

The third hypothesis focused on whether there was a statistically significant difference between the middle school students' achievement scores for the ELA and mathematics examinations and the overall rating their school's band received at the District Concert Band MPA for the 2015-2016 school year. The second and third hypotheses provided a deeper insight on a possible link that a band program's inclusion 
in the school's curriculum could have on a middle school's academic achievement and academic culture.

\section{Statistical Treatment}

After the data were collected from all the aforementioned sources, statistical testing took place. For the first hypothesis, an independent-samples $t$-test was used to test the group mean differences between a middle school student's District Concert Band MPA participation versus nonparticipation and their ELA and mathematics achievement scores for the 2015-2016 school year. The means for the two middle school groups in the study (Group 1 being the two high-performing middle schools and Group 2 being the two low-performing middle schools), as well as the means of all four schools combined were analyzed for statistical significance. Field (2009) defines an independent-samples $t$-test as a statistical procedure used to test whether two means collected from independent samples differ significantly.

The second and third hypotheses dealt with those middle school students that participated in the District Concert Band Music Performance Assessment (MPA). Since only two of the three possible music classification levels of music were used (MC and MB) and only two of the five possible final ratings were used in this study (Superior and Good), an independent-samples $t$-test was also used to test the group mean differences between ELA and mathematics achievement scores and the level of music the student's band performed, as well as their band's final overall rating at the District Concert Band MPA for the 2015-2016 school year. 


\section{Summary}

The study aimed at testing the relationship between a middle school student's Music Performance Assessment (MPA) participation and Florida Standards Assessments (FSA) English language arts (ELA) and mathematics achievement. Four of the MiamiDade County Public Middle Schools were selected for this study. Schools 1 and 2 were high-achieving middle schools with an active, established band program. Schools 3 and 4 were low-achieving middle schools with an active, established band program. These four schools were selected from the Miami-Dade County Public School District.

An independent-samples $t$-test was used to test the mean differences between a middle school student's District Music Performance Assessment (MPA) participation versus nonparticipation and Florida Standards Assessments (FSA) achievement scores. Because only two of the three possible music classification levels of music were used (MC and $\mathrm{MB}$ ) and only two of the five possible final ratings were used in this study (Superior and Good), an independent-samples $t$-test was also used to test the mean differences between FSA achievement scores and the level of music the student's band performed at the MPA and the mean differences between FSA achievement scores and the student's band's overall rating at the MPA for 2015-2016 school year.

Middle school student's District Concert Band Music Performance Assessment Participation versus nonparticipation, a student's band's overall rating, and level of music the band performed were examined in this research. The criterion variables that were used for this study are Florida Standards Assessments (FSA) English language arts achievement scores for Grades 6, 7, and 8 collectively, and Florida Standards Assessments (FSA) mathematics achievement scores for Grades 6, 7, and 8 collectively. 


\section{CHAPTER IV}

\section{DATA ANALYSIS AND RESULTS}

The purpose of this ex post facto study was to determine the link between middle school students' participation in the 2016 concert band music performance assessment (MPA) and student achievement on the 2016 English language arts (ELA) and mathematics subtests of the Florida Standards Assessments (FSA). The variables included in this study were Concert Band MPA participation versus nonparticipation, the level of music performed, the band's final overall rating, and FSA ELA and mathematics achievement scores. This chapter presents the descriptive and inferential statistics of the collected data in accordance with the procedures that were outlined in Chapter III, as well as a summary of the results.

\section{Descriptive Statistics}

The descriptive statistics for the average 2016 FSA scores (ELA and mathematics) were collected from the four middle schools that were used in the study (schools 1 and 2 were high-achieving schools, while schools 3 and 4 were low-achieving schools). Two groups of students were created from each of the four schools used in the study: Group 1 was comprised of those students that participated in their respective school's Concert Band MPA and Group 2 was comprised of the students that did not participate in their school's Concert Band MPA; Group 2 was created via a stratified random sampling from the school's population.

The means for the average ELA achievement scores were higher for the groups that participated in the Concert Band MPA by 1.29 for School 1, 1.22 for School 2, .74 for School 3, and .47 for School 4. The means for the average ELA achievement scores 
were higher for the groups that participated in the Concert Band MPA for Schools 1 and 2 combined (the high-achieving schools) by 1.26 and the means for the average ELA achievement scores were higher for the groups that participated in the Concert Band MPA for Schools 3 and 4 combined (the low-achieving schools) by .63. In addition, the total means from all four schools combined for the average ELA achievement scores were higher for the groups that participated in the Concert Band MPA by 1.00.

Additionally, the means for the average mathematics achievement scores were higher for the groups that participated in the Concert Band MPA by .80 for School 1, .70 for School 2, .26 for School 3, and .69 for School 4. The means for the average mathematics achievement scores were higher for the groups that participated in the Concert Band MPA for Schools 1 and 2 combined (the high-achieving schools) by .75 and the means for the average mathematics achievement scores were higher for the groups that participated in the Concert Band MPA for Schools 3 and 4 combined (the low-achieving schools) by .44. Additionally, the total means from all four schools combined for the average mathematics achievement scores were higher for the groups that participated in the Concert Band MPA by .62 .

Tables 5-16 below display the numerical average means based on the average ELA and mathematics achievement scores of the 2016 FSA administration. The tables display the average mean ELA and mathematics achievement scores of those students that participated in the 2016 Concert Band MPA versus those that did not participate from each of the four schools that were used in the study, as well as the average mean ELA and mathematics achievement scores of the high-achieving schools combined, the low-achieving schools combined, and all four schools combined. In these charts, 0 
represented nonparticipation and 1 represented Concert Band MPA participation. The average means were calculated via the Statistical Package for the Social Sciences (SPSS) 23 computer program:

Table 5

Means of the FSA ELA Achievement Scores for School 1

\begin{tabular}{cccc}
\hline Participate & $N$ & Mean & $\begin{array}{c}\text { Standard } \\
\text { Deviation }\end{array}$ \\
\hline 1 & 45 & 3.82 & .984 \\
0 & 45 & 2.53 & 1.236 \\
\hline
\end{tabular}

Table 6

Means of the FSA ELA Achievement Scores for School 2

\begin{tabular}{cccc}
\hline Participate & $N$ & Mean & $\begin{array}{c}\text { Standard } \\
\text { Deviation }\end{array}$ \\
\hline 1 & 44 & 3.77 & 1.008 \\
0 & 44 & 2.55 & 1.266 \\
\hline
\end{tabular}

Table 7

Means of the FSA ELA Achievement Scores for School 3

\begin{tabular}{cccc}
\hline Participate & $N$ & Mean & $\begin{array}{c}\text { Standard } \\
\text { Deviation }\end{array}$ \\
\hline 1 & 38 & 3.16 & 1.175 \\
0 & 38 & 2.42 & 1.130 \\
\hline
\end{tabular}


Table 8

Means of the FSA ELA Achievement Scores for School 4

\begin{tabular}{cccc} 
Participate & $N$ & Mean & $\begin{array}{c}\text { Standard } \\
\text { Deviation }\end{array}$ \\
\hline 1 & 26 & 2.62 & 1.134 \\
0 & 26 & 2.15 & .925
\end{tabular}

Table 9

Means of the FSA Mathematics Achievement Scores for School 1

\begin{tabular}{cccc}
\hline Participate & $N$ & Mean & $\begin{array}{c}\text { Standard } \\
\text { Deviation }\end{array}$ \\
\hline 1 & 45 & 3.56 & .755 \\
0 & 45 & 2.76 & .830 \\
\hline
\end{tabular}

Table 10

Means of the FSA Mathematics Achievement Scores for School 2

\begin{tabular}{cccc}
\hline Participate & $N$ & Mean & $\begin{array}{c}\text { Standard } \\
\text { Deviation }\end{array}$ \\
\hline 1 & 44 & 3.50 & .762 \\
0 & 44 & 2.80 & .851 \\
\hline
\end{tabular}


Table 11

Means of the FSA Mathematics Achievement Scores for School 3

\begin{tabular}{cccc} 
Participate & $N$ & Mean & $\begin{array}{c}\text { Standard } \\
\text { Deviation }\end{array}$ \\
\hline 1 & 38 & 2.76 & 1.076 \\
0 & 38 & 2.50 & .923 \\
\hline
\end{tabular}

Table 12

Means of the FSA Mathematics Achievement Scores for School 4

\begin{tabular}{cccc}
\hline Participate & $N$ & Mean & $\begin{array}{c}\text { Standard } \\
\text { Deviation }\end{array}$ \\
\hline 1 & 26 & 3.15 & .881 \\
0 & 26 & 2.46 & .905 \\
\hline
\end{tabular}

Table 13

Means of the FSA ELA and Mathematics Achievement Scores for the High-Achieving Schools (Schools 1 and 2 combined)

\begin{tabular}{ccccc} 
Test & Participate & $N$ & Mean & $\begin{array}{c}\text { Standard } \\
\text { Deviation }\end{array}$ \\
\hline ELA & 1 & 89 & 3.80 & .991 \\
& 0 & 89 & 2.54 & 1.244 \\
Mathematics & 1 & 89 & 3.53 & .755 \\
& 0 & 89 & 2.78 & .836 \\
\hline
\end{tabular}


Table 14

Means of the FSA ELA and Mathematics Achievement Scores for the Low-Achieving Schools (Schools 3 and 4 combined)

\begin{tabular}{ccccc}
\hline Test & Participate & $N$ & Mean & $\begin{array}{c}\text { Standard } \\
\text { Deviation }\end{array}$ \\
\hline ELA & 1 & 64 & 2.94 & 1.18 \\
& 0 & 64 & 2.31 & 1.05 \\
Mathematics & 1 & 64 & 2.92 & 1.01 \\
& 0 & 64 & 2.48 & .91 \\
\hline
\end{tabular}

Table 15

Means of the FSA ELA Achievement Scores for All Four Schools Combined

\begin{tabular}{cccc}
\hline Participate & $N$ & Mean & $\begin{array}{c}\text { Standard } \\
\text { Deviation }\end{array}$ \\
\hline 1 & 153 & 3.44 & 1.152 \\
0 & 153 & 2.44 & 1.169 \\
\hline
\end{tabular}

Table 16

Means of the Mathematics Achievement Scores for All Four Schools Combined

\begin{tabular}{cccc}
\hline Participate & $N$ & Mean & $\begin{array}{c}\text { Standard } \\
\text { Deviation }\end{array}$ \\
\hline 1 & 153 & 3.27 & .919 \\
0 & 153 & 2.65 & .876 \\
\hline
\end{tabular}


To present a visual representation of the descriptive statistics, box plots were graphed based on the average FSA ELA and mathematics achievement scores. The box plots illustrate the distribution of the average ELA and mathematics scores in relation to Concert Band MPA participation versus nonparticipation. 0 on the $\mathrm{x}$-axis of the box plot indicates nonparticipation and 1 represents participation. $1-5$ on the y-axis of the box plot represents the ELA and mathematics achievement scores. Figures 4-17 below contain the box plots which illustrates the descriptive statistics:

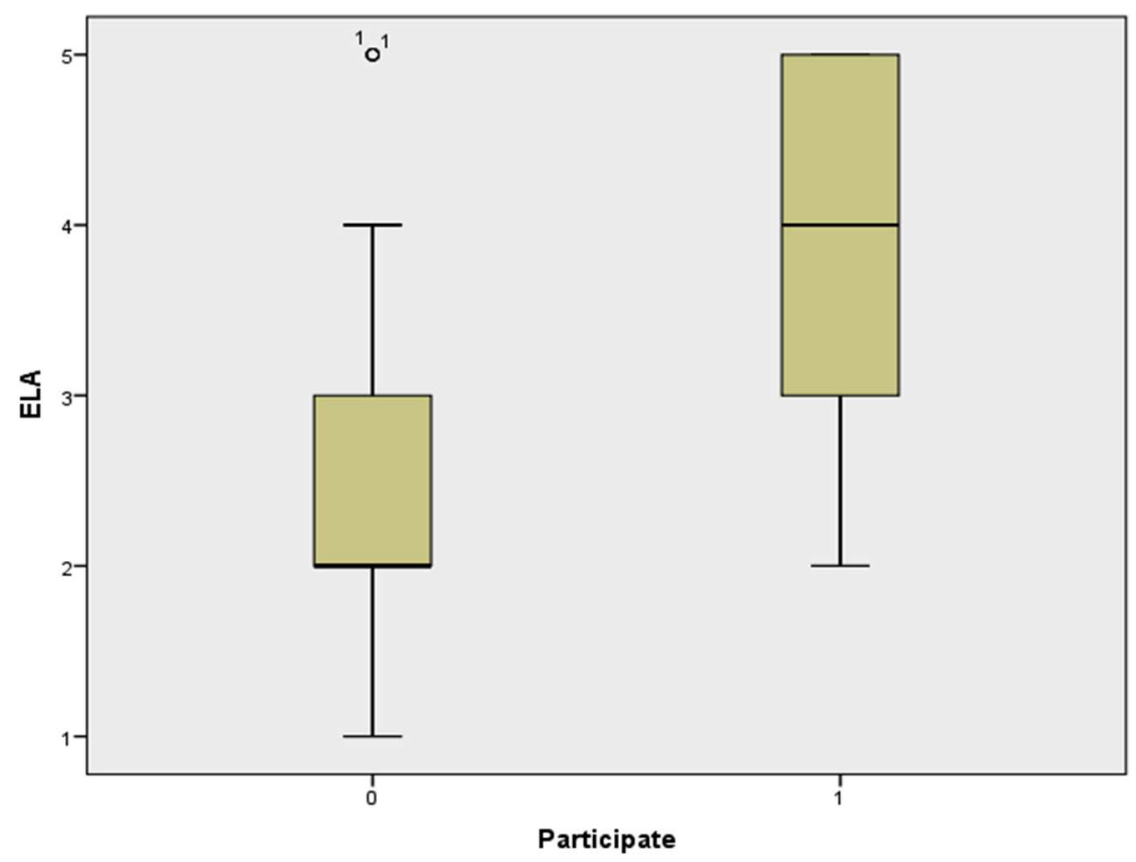

Figure 4. Box plot illustrating the distribution of the ELA scores for School 1. 


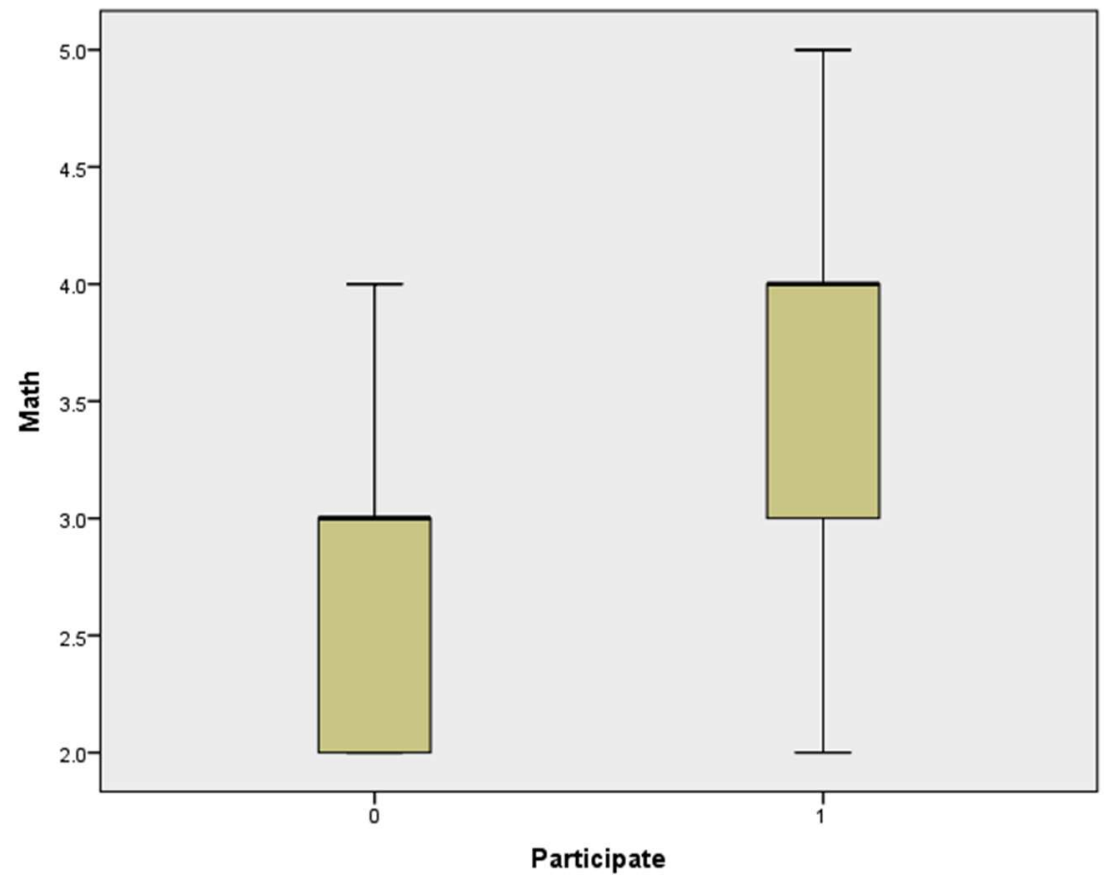

Figure 5. Box plot illustrating the distribution of the mathematics scores for School 1.

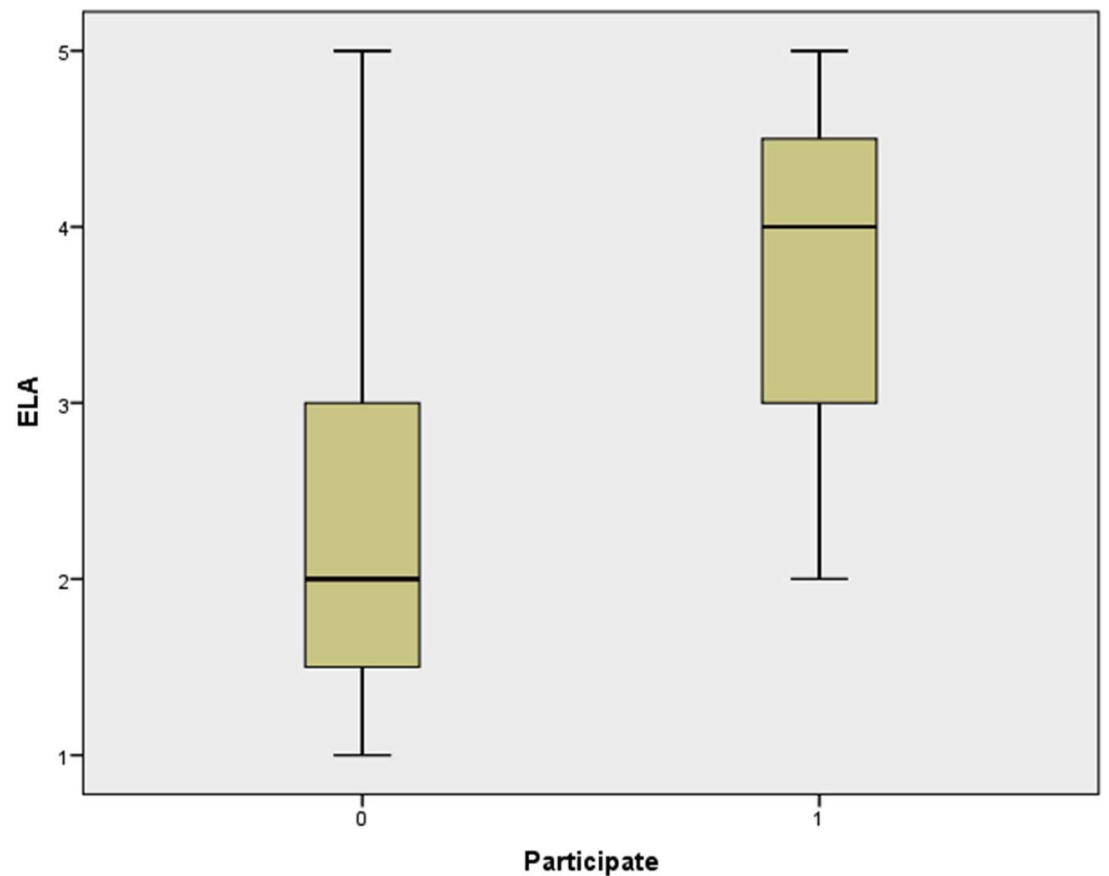

Figure 6. Box plot illustrating the distribution of the ELA scores for School 2. 


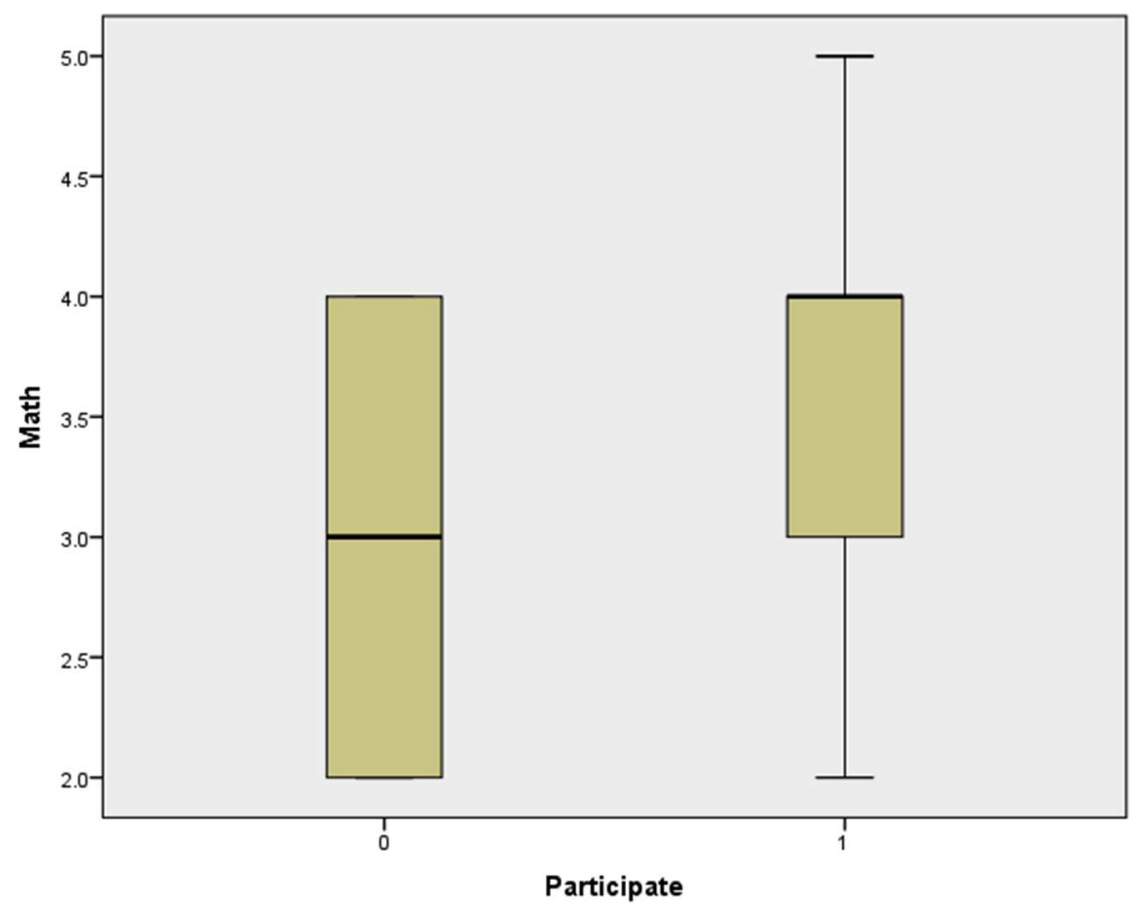

Figure 7. Box plot illustrating the distribution of the mathematics scores for School 2.

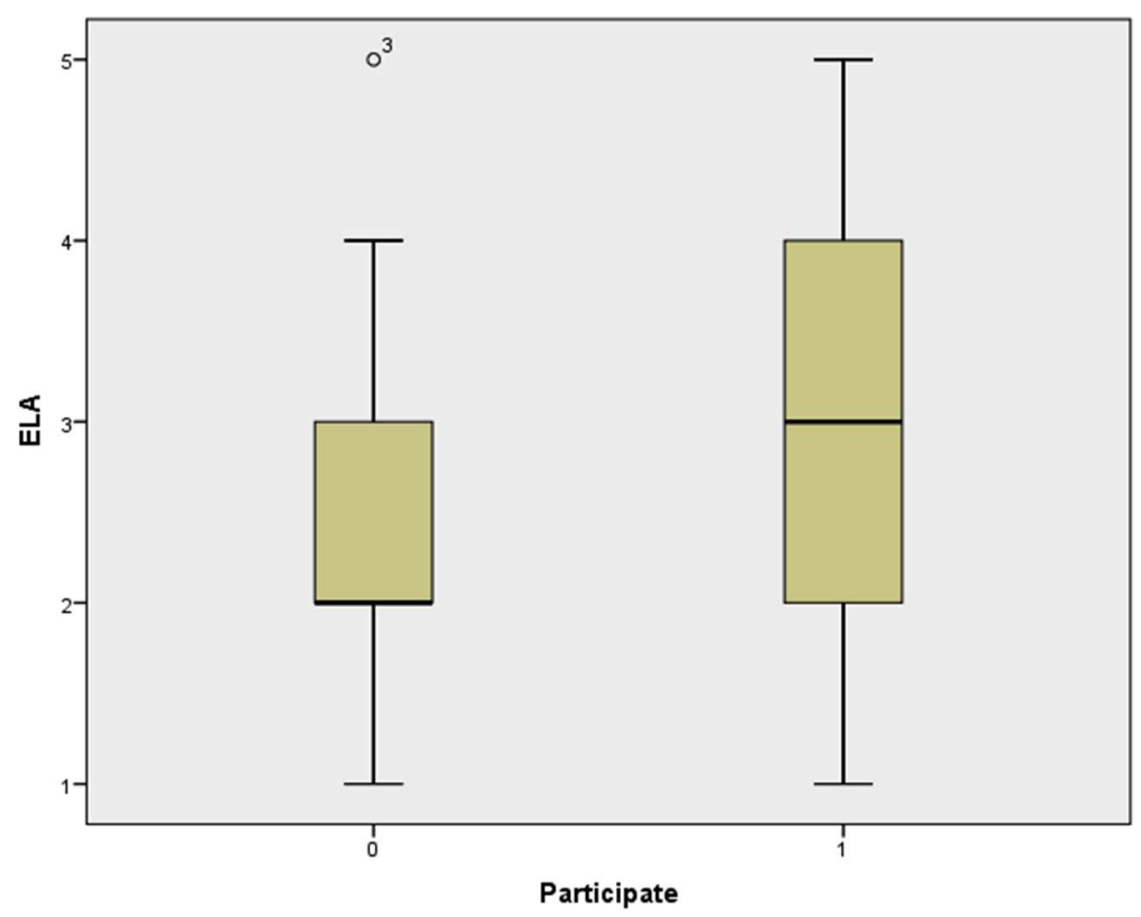

Figure 8. Box plot illustrating the distribution of the ELA scores for School 3. 


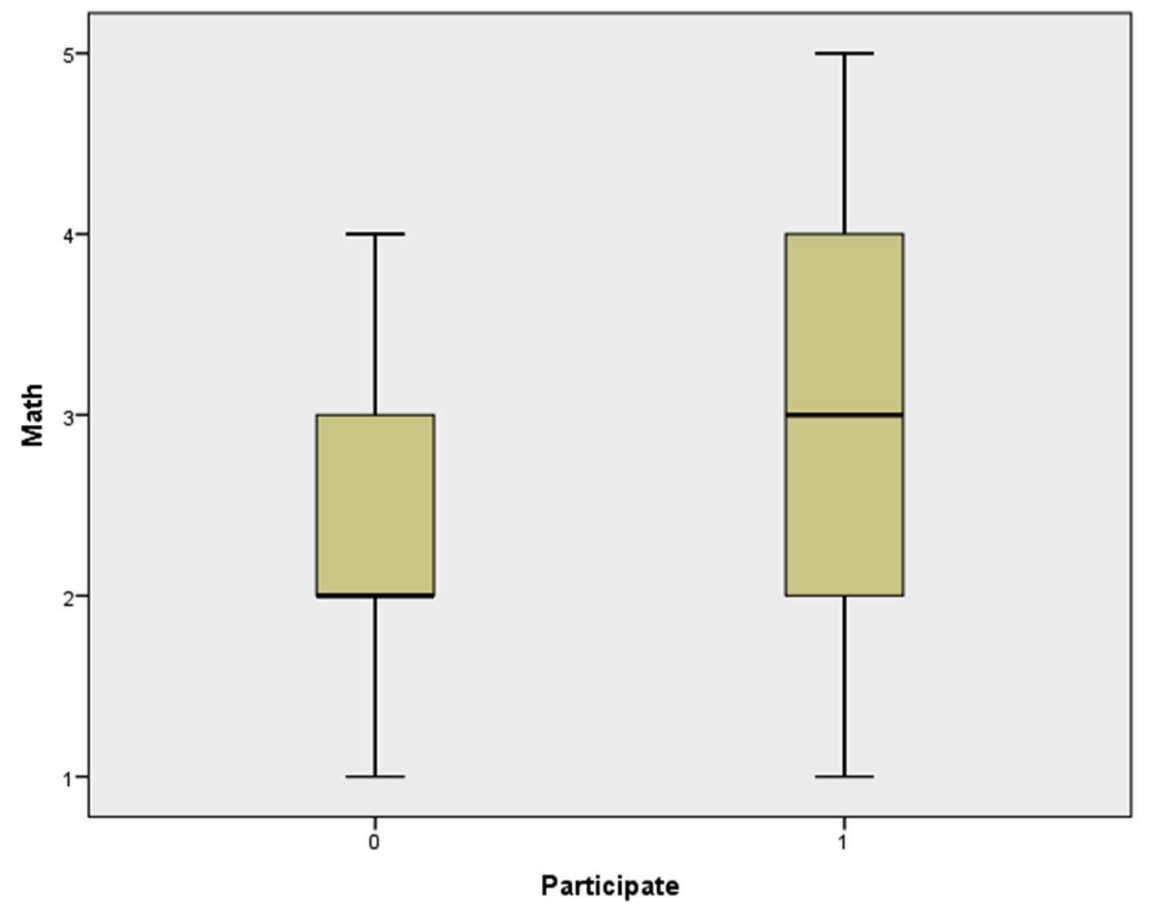

Figure 9. Box plot illustrating the distribution of the mathematics scores for School 3.

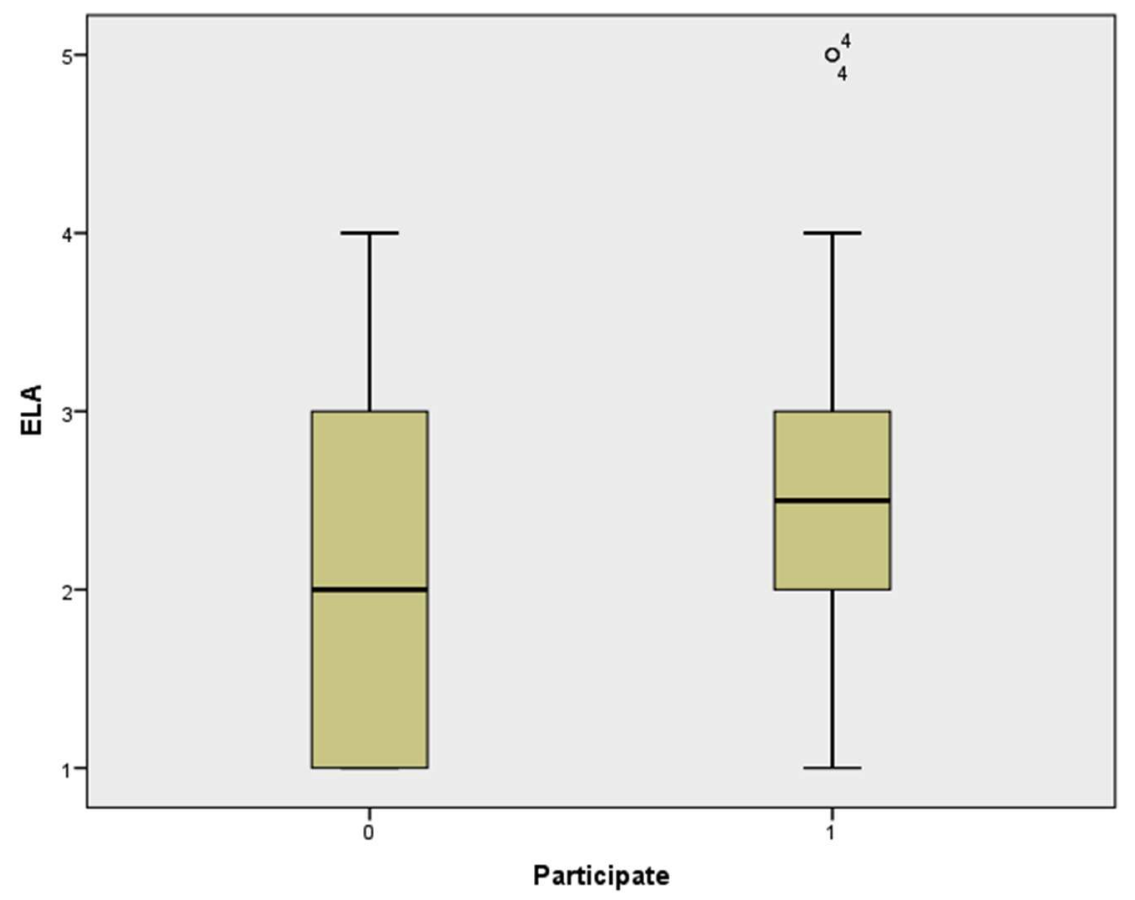

Figure 10. Box plot illustrating the distribution of the ELA scores for School 4. 


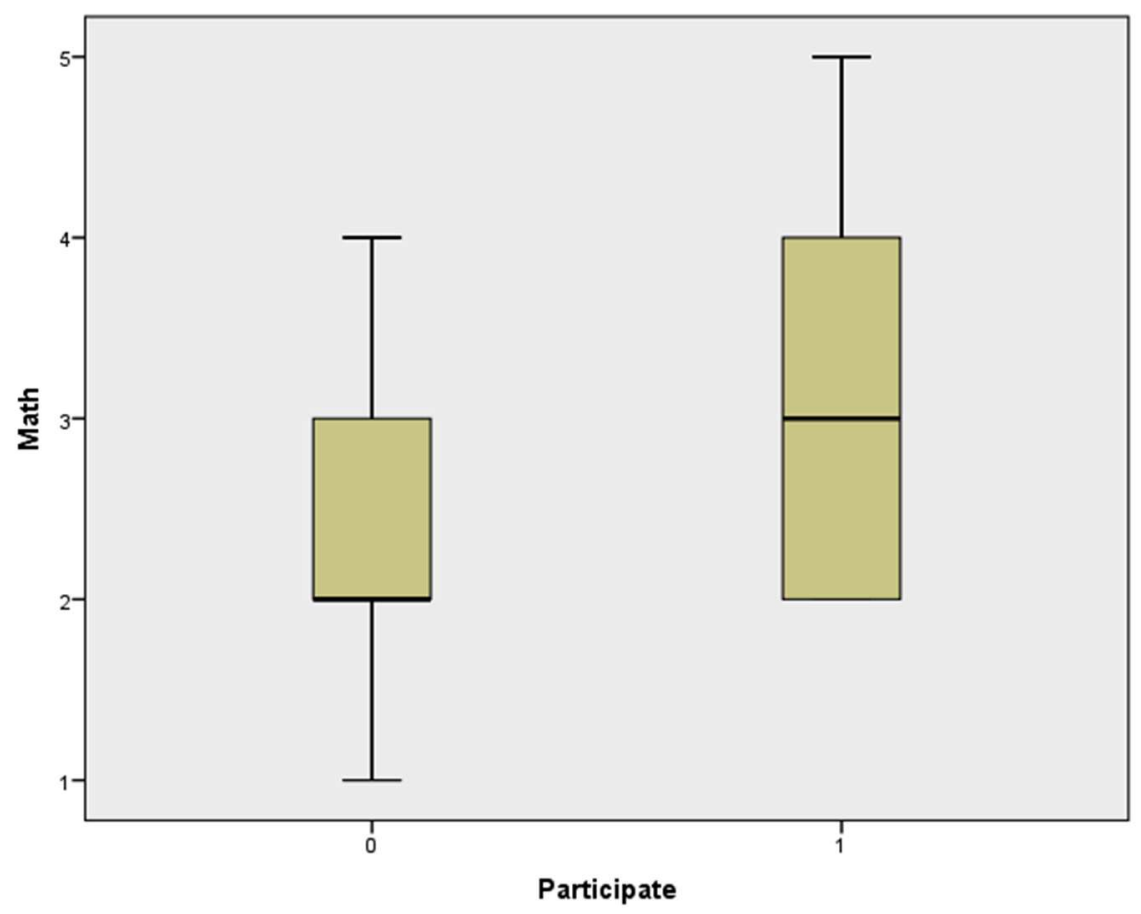

Figure 11. Box plot illustrating the distribution of the mathematics scores for School 4.

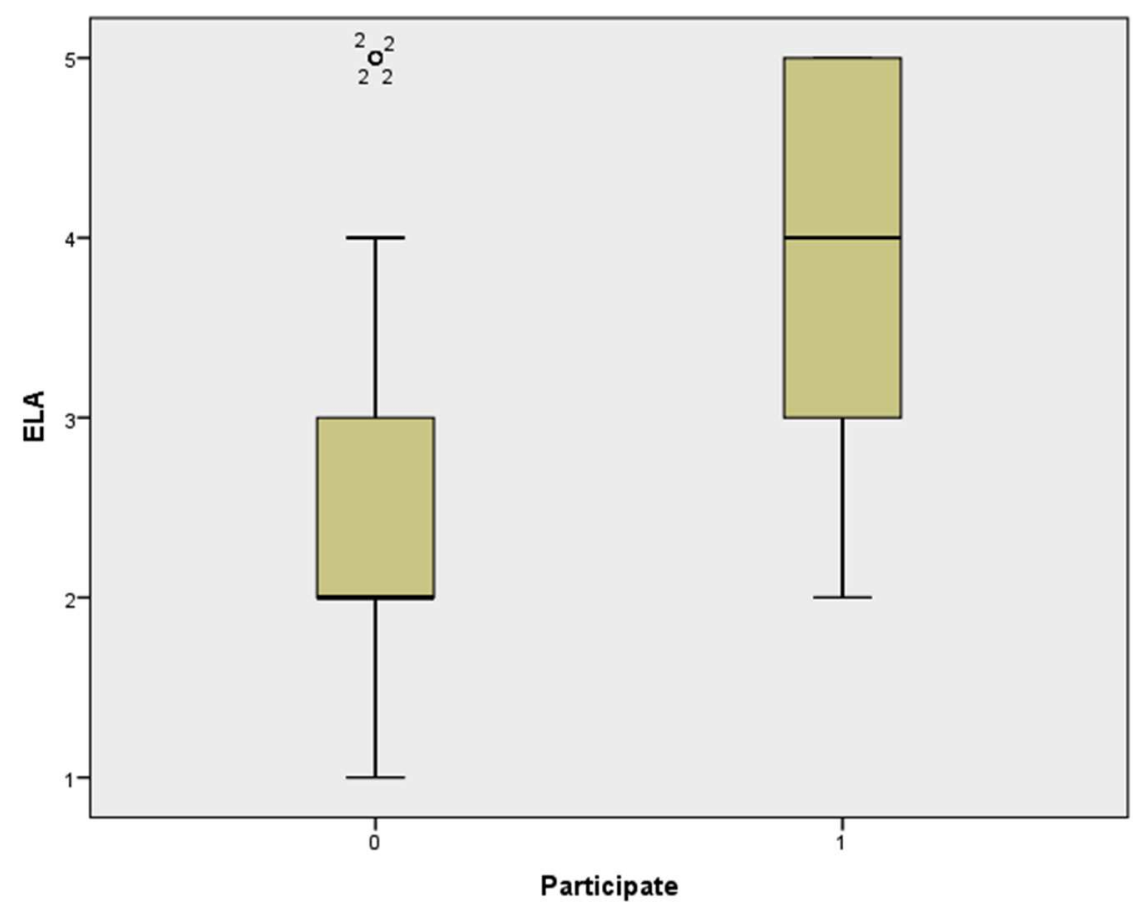

Figure 12. Box plot illustrating the distribution of the ELA scores for the high-achieving schools (Schools 1 and 2 combined). 


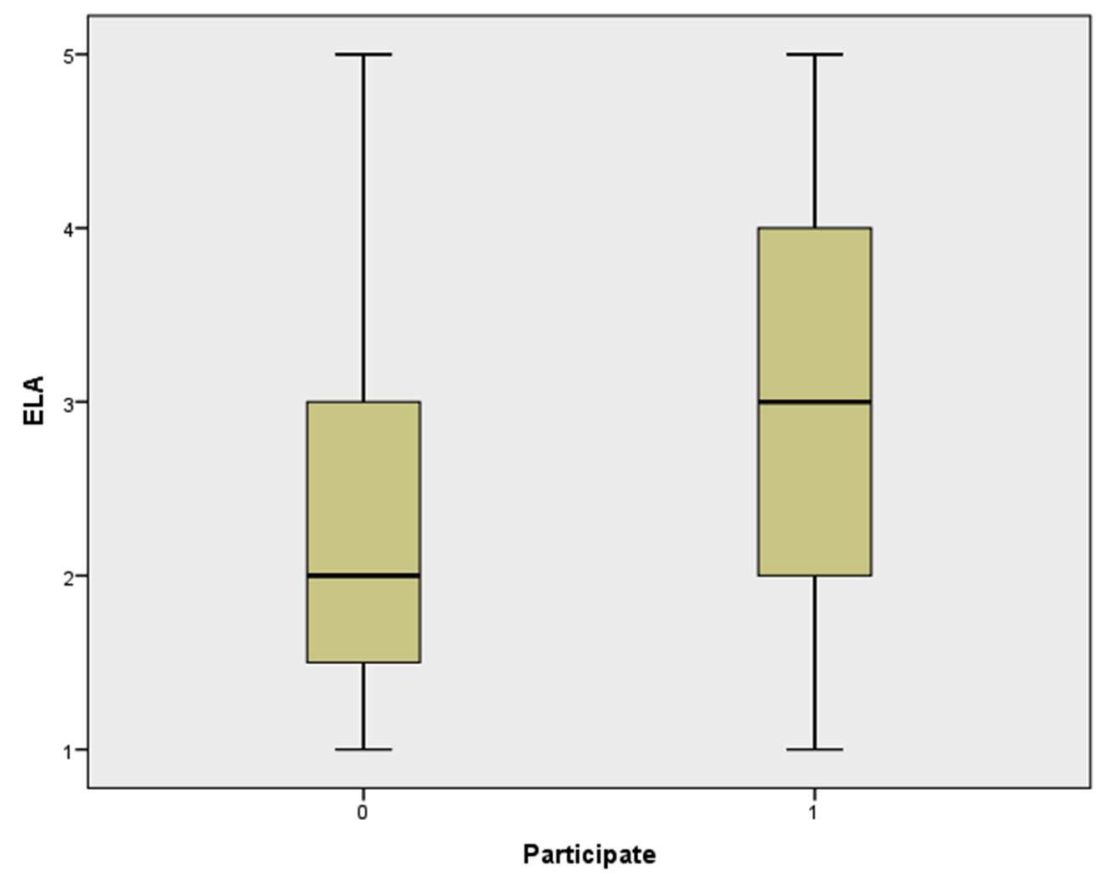

Figure 13. Box plot illustrating the distribution of the ELA scores for the low-achieving schools (Schools 3 and 4 combined).

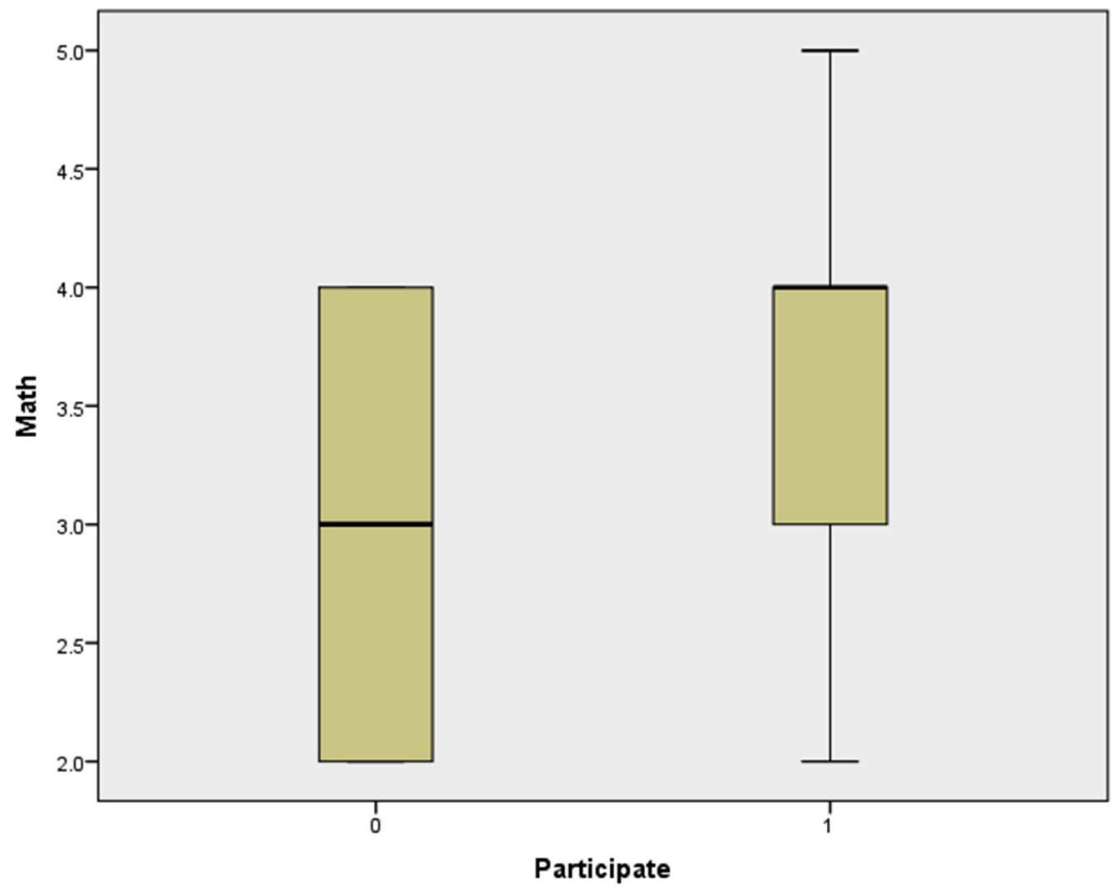

Figure 14. Box plot illustrating the distribution of the mathematics scores for the highachieving schools (Schools 1 and 2 combined). 


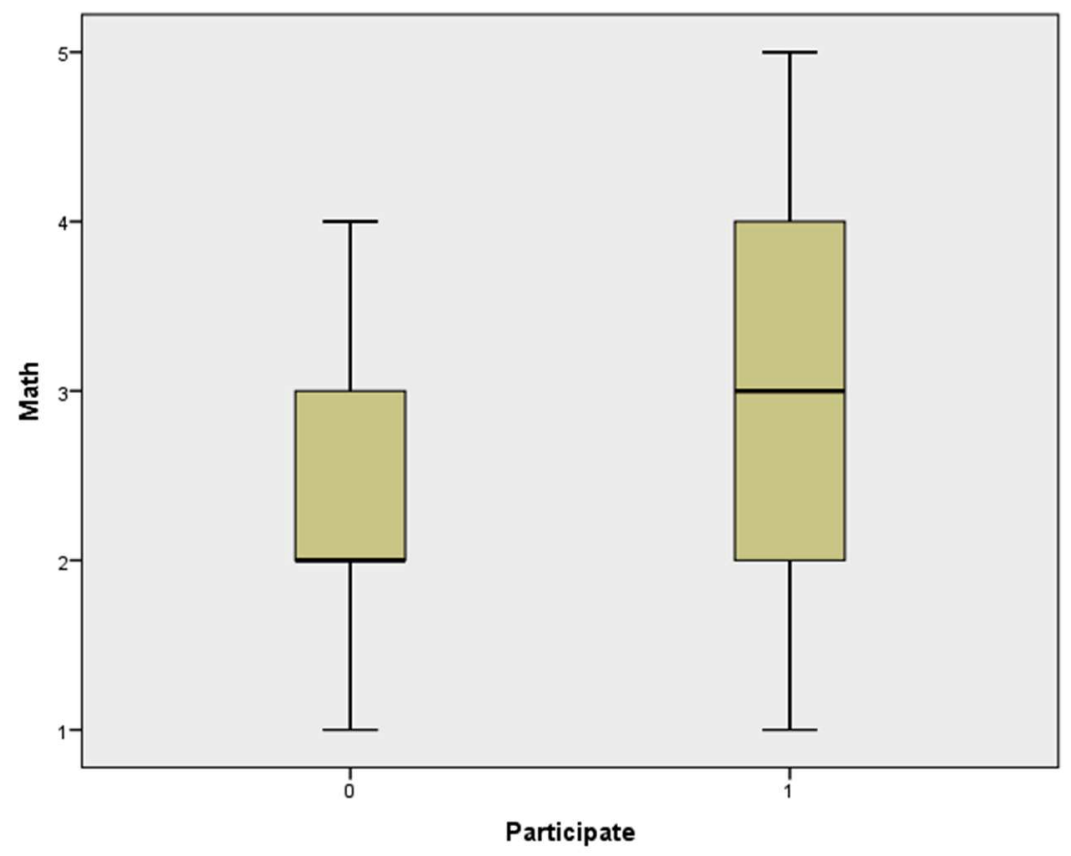

Figure 15. Box plot illustrating the distribution of the mathematics scores for the lowachieving schools (Schools 3 and 4 combined).

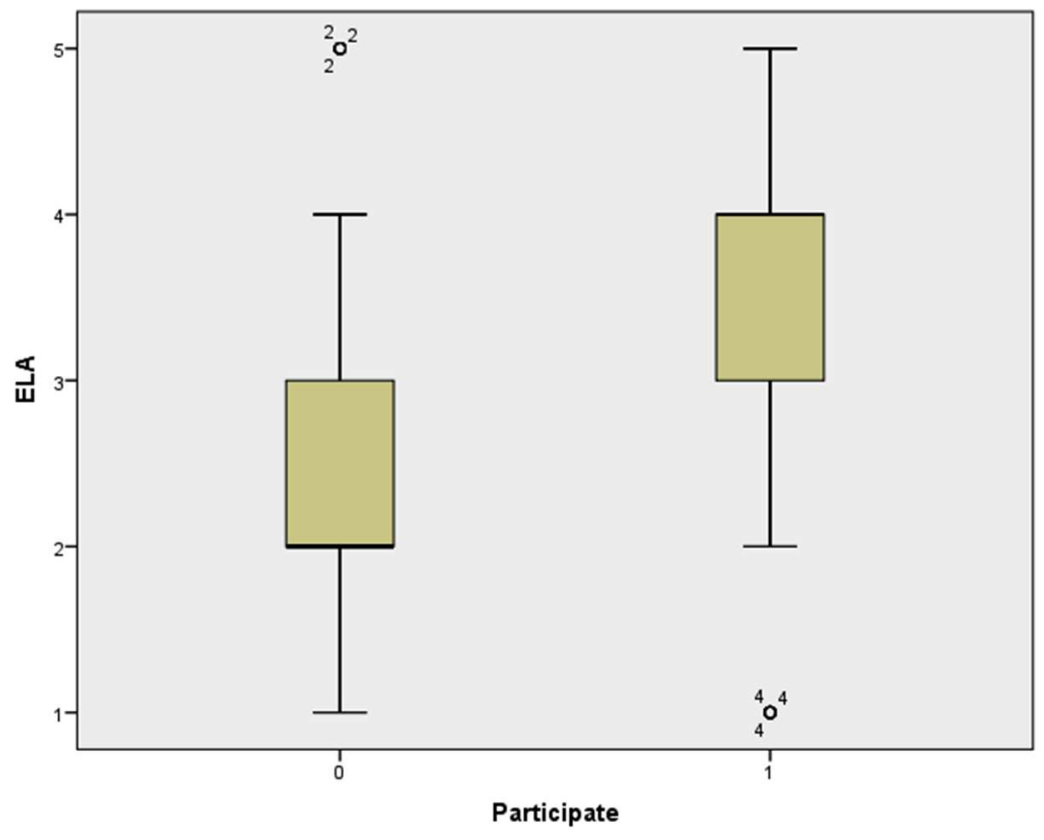

Figure 16. Box plot illustrating the distribution of the ELA scores for all four schools combined. 


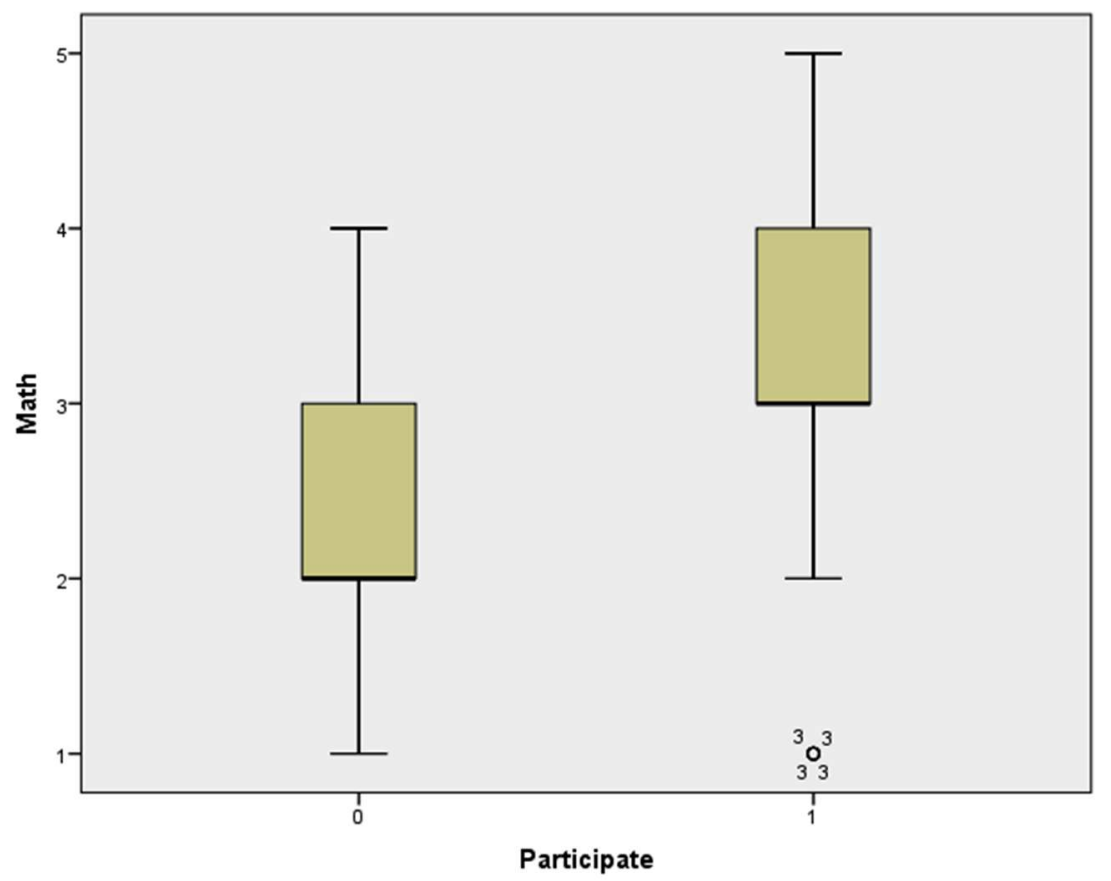

Figure 17. Box plot illustrating the distribution of the mathematics scores for all four schools combined.

These box plots clearly illustrate that the students who participated in the Concert Band MPA had higher FSA ELA and mathematics scores than those that did not participate. At this point, a statistical test was needed to determine if a statistically significant difference exists. As a result, the collection and analysis of inferential statistics was necessary to determine whether or not a statistically significant difference was present.

\section{Inferential Statistics}

At this point, statistical analyses were conducted via the SPSS 23 computer program to test the three research hypotheses. An independent-samples $t$-test was first conducted at the alpha .05 level to determine if a statistically significant difference was shown between the students that participated in the Concert Band MPA and those that did not participate regarding their ELA and mathematics achievement scores. 


\section{Research Hypothesis 1}

Here is where the statistical test of Research Hypothesis 1 began. For the highachieving group (Schools 1 and 2), there was a statistically significant difference between the ELA achievement scores of those students that participated in the 2016 Concert Band MPA $(M=3.80, S D=.991)$ and those that did not participate $(M=2.54, S D=1.24)$; $t(168)=7.47, p<.001$. There was also a statistically significant difference between the mathematics achievement scores of those students that participated in the 2016 Concert Band MPA $(M=3.53, S D=.76)$ and those that did not participate $(M=2.78, S D=.84)$; $t(176)=6.30, p<.001$

For the low-achieving group (Schools 3 and 4), there was a statistically significant difference between the ELA achievement scores of those students that participated in the 2016 Concert Band MPA $(M=2.94, S D=1.18)$ and those that did not participate $(M=$ $2.31, S D=1.05) ; t(126)=3.16, p=.002$. There was also a statistically significant difference between the mathematics achievement scores of those students that participated in the 2016 Concert Band MPA $(M=2.92, S D=1.01)$ and those that did not participate $(M=2.48, S D=.91) ; t(126)=2.57, p=.011$.

Tables 17-18 show the possible differences between the students' participation in the Concert Band MPA and their ELA and mathematics scores for the two groups of schools that were used for the study (high-achieving group and low-achieving group). 
Table 17

Independent-Samples $t$-Test of the Students' ELA and Mathematics Achievement Scores from the High-Achieving Schools and Concert Band MPA Participation

$$
\begin{array}{llllll}
\text { Test } & F & \text { Sig. } & t & d f & \text { Sig. }
\end{array}
$$

ELA

Equal variances assumed

Equal variances not assumed

Math

Equal variances assumed

Equal variances not assumed

$\begin{array}{lllll}8.699 & .004 & 7.467 & 176.000 & .000 \\ & & 7.467 & 167.617 & .000\end{array}$

2.913

.090

$6.304 \quad 176.000$

.000

$6.304 \quad 174.208 \quad .000$

Table 18

Independent-Samples t-Test of the Students' ELA and Mathematics Achievement Scores from the Low-Achieving Schools and Concert Band MPA Participation

$$
\text { Test } \quad F \quad \text { Sig. } \quad t \quad d f
$$

(2-tailed)

ELA

Equal variances assumed

.424

.516

$3.162 \quad 126.000$

.002

Equal variances not assumed

$3.162 \quad 124.376$

.002

Math

Equal variances assumed

.177

$\begin{array}{lll}.675 & 2.573 & 126.000\end{array}$

.011

Equal variances not assumed 
Additionally, when combining the high achieving and low achieving schools' scores together, there was a statistically significant difference between the ELA achievement scores of those students that participated in the 2016 Concert Band MPA ( $M$ $=3.44, S D=1.15)$ and those that did not participate $(M=2.44, S D=1.17) ; t(304)=7.49$, $p<.001$. There was also a statistically significant difference between the mathematics achievement scores of those students that participated in the 2016 Concert Band MPA ( $M$ $=3.27, S D=.92)$ and those that did not participate $(M=2.65, S D=.88) ; t(304)=6.05, p$ $<.001$.

Table 19 below shows the results of the statistical tests. With these positive statistical results, the null hypothesis for Research Hypothesis 1 was rejected and the statistical testing of Hypotheses 2 and 3 began.

Table 19

Independent-Samples t-Test of the Students' ELA and Mathematics Achievement Scores from All of the Schools Combined and Concert Band MPA Participation

$\begin{array}{llllll}\text { Test } & F & \text { Sig. } & t & d f & \text { Sig. }\end{array}$

ELA

Equal variances assumed

.012

$\begin{array}{rrrr}.913 & 7.487 & 304.000 & .000 \\ & 7.487 & 303.932 & .000\end{array}$

Math

Equal variances assumed .026 .873

$6.048 \quad 304.000$

.000

Equal variances not assumed

$6.048 \quad 303.294 \quad .000$




\section{Research Hypothesis 2}

Once the statistical tests supported the positive link between Concert Band MPA participation and ELA and mathematics achievement scores, the statistical test of Research Hypothesis 2 began. Research Hypothesis 2 sought to test the differences between the students' ELA and mathematics achievement scores and the level of music that the students performed at the Concert Band MPA.

At the alpha .05 level, the results of the statistical test showed that for those students that did participate in the 2016 Concert Band MPA, there was a statistically significant difference between the ELA achievement scores of those students that performed music from the MB level, which is the higher-level music $(M=3.80, S D=$ $.99)$ and those that performed music from the MC level, which is the lower-level music $(M=2.94, S D=1.18) ; t(151)=-4.89, p<.001$.

The results of the statistical analyses also showed that for those students that did participate in the 2016 Concert Band MPA, there was a statistically significant difference between the mathematics achievement scores of those students that performed music from the MB level, which is the higher-level music $(M=3.53, S D=.76)$ and those that performed music from the MC level, which is the lower-level music $(M=2.92, S D=$ $1.01) ; t(111)=-4.05, p<.001$. Table 20 shows the independent-samples $t$-test analyses of the students' ELA and mathematics scores and the level of music that the students performed at the Concert Band MPA. 
Table 20

Independent-Samples $t$-Test of the Students' ELA and Mathematics Achievement Scores and the Level of Music Performed at the Concert Band MPA

$\begin{array}{llllll}\text { Test } & F & \text { Sig. } & t & d f & \text { Sig. }\end{array}$

ELA

Equal variances assumed

2.376

.125

$-4.888 \quad 151.000$

.000

Equal variances not assumed

$\begin{array}{lll}-4.751 & 120.809 \quad .000\end{array}$

Math

Equal variances assumed

4.451

.037

$-4.242 \quad 151.000$

.000

Equal variances not assumed

$-4.048 \quad 110.773 \quad .000$

\section{Research Hypothesis 3}

Research Hypothesis 3 sought to test the relationship between the students' ELA and mathematics achievement scores and the final overall rating that their band received at the Concert Band MPA. At the alpha .05 level, the results of the statistical test showed that for those students that did participate in the 2016 Concert Band MPA, even though the mean of the ELA achievement scores of those students whose band received a final rating of superior $(M=3.52, S D=1.12)$ was higher than those students whose band received a final rating of good $(M=3.34, S D=1.19)$; there was not a statistically significant difference $t(151)=.94, p>.05$. Therefore, the hypothesis was not supported.

The results of the statistical test also showed that for those students that did participate in the 2016 Concert Band MPA, the mean of the mathematics achievement scores of those students whose band received a final rating of $\operatorname{good}(M=3.37, S D=.82)$ was actually higher than those students whose band received a final rating of superior ( $M$ 
$=3.19, S D=.99)$; there was not a statistically significant difference $t(151)=-1.20, p>$ .05 . Table 21 shows the independent-samples $t$-test analyses of the students' ELA and mathematics scores and the final overall rating that their band received at the Concert Band MPA.

Table 21

Independent-Samples t-Test of the Students' ELA and Mathematics Achievement Scores and the Final Overall Rating that their Band Received at the Concert Band MPA

$\begin{array}{llllll}\text { Test } & F & \text { Sig. } & t & d f & \text { Sig. }\end{array}$

ELA

Equal variances assumed

.799

$\begin{array}{llll}.373 & .937 & 151.000 & .350\end{array}$

Equal variances not assumed

$\begin{array}{lll}.932 & 143.244 \quad .353\end{array}$

Math

Equal variances assumed

$\begin{array}{lllll}1.309 & .254 & -1.199 & 151.000 & .232\end{array}$

Equal variances not assumed

$-1.219 \quad 150.935 \quad .225$

\section{Summary}

The results of the statistical analyses showed that for Research Hypothesis 1, there was a statistically significant difference at the alpha .05 level between the FSA ELA achievement scores of those students that participated in the 2016 Concert Band MPA and those that did not participate. There was also a statistically significant difference at the alpha .05 level between the mathematics achievement scores of those students that participated in the 2016 Concert Band MPA and those that did not participate. At this 
point, the null hypothesis was rejected and hypotheses 2 and 3 were tested for statistical significance.

For those students that participated in the 2016 Concert Band MPA, a statistically significant difference at the alpha .05 level was shown between the students' FSA ELA achievement scores and the level of music that their band performed at the Concert Band MPA. Additionally, for those students that participated in the 2016 Concert Band MPA, a statistically significant difference at the alpha .05 level was shown between the students' mathematics achievement scores and the level of music that their band performed at the Concert Band MPA.

For those students that participated in the 2016 Concert Band MPA, there was not a statistically significant difference between the students' FSA ELA or mathematics achievement scores and the final rating that their band received at the 2016 Concert Band MPA, even though the mean of the ELA achievement scores of those students whose band received a final rating of superior was higher than those students whose band received a final rating of good. Additionally, the mean of the mathematics achievement scores of those students whose band received a final rating of good was actually higher than those students whose band received a final rating of superior. Chapter 5 will address the outcome of these results as well as the implications they can have for further research, theory, and practice. 


\section{CHAPTER V}

\section{SUMMARY, CONCLUSIONS, AND IMPLICATIONS}

This chapter serves as a comprehensive summary of the study. It also discusses the results of the study as well as further implications for research, theory, and practice within the field of education. The study seeks to contribute to the body of knowledge the notion of the positive correlation between music study in schools and student achievement.

\section{Summary of the Study}

Since the advent of standardized testing and the tremendous high-stakes pressure that has been placed on schools to pass these tests throughout the State of Florida and the United States, school principals and other administrators are charged with the responsibility of ensuring that their students are successful with these tests. However, far too often, one of the courses of action that administrators seem to take is to eliminate elective course offerings, such as music, to those students that are not on "achievement level" in accordance to these standardized tests.

However, there is a great deal of research which shows the positive link between music education in schools and high student achievement (Bryan \& Dorrington, 2004; Demorest \& Morrison, 2000; Geist \& Geist, 2008; Register, Darrow, Standley, \& Swedberg, 2007; Wetter, Koerner, \& Schwaninger, 2009; Woody, 1998). Throughout the country, middle schools seem to suffer with the biggest instance of an achievement gap (West \& Schwerdt, 2012) and for a middle school to be successful and most beneficial for the student, it is supposed to be exploratory in nature (Gilstrap, 1994). Therefore, when administrators strip students of the opportunity to have elective classes 
such as music, they are antagonizing the primary purpose of a middle school education; this is typically the time when the young teenaged students are trying to discover their interests to start shaping their future careers and lives.

The purpose of this study was to examine the link between those middle school students that participate in the Concert Band MPA and student achievement on the ELA and mathematics subtests of the FSA. The study also examined the differences between the level of music that was performed at the MPA and student achievement on the FSA, as well as the student's band overall final rating at the MPA and student achievement on the FSA. The theoretical framework of this study was Howard Gardner's theory of multiple intelligences. His theory includes nine intelligences, in which one of the intelligences is music. He feels that standardized testing has placed an overemphasis on reading and mathematics; however, the mind is more complex in nature (Gardner \& Hatch, 1989). Additionally, the music intelligence runs in a nearly structural parallel to the linguistic and mathematical intelligences (Gardner, 2011; McFarlane, 2011). Three research questions were addressed in this study:

1. Is there a correlation between a middle school student's District Concert Band MPA participation and FSA ELA and Mathematics achievement scores?

2. For the middle school students that did participate in the District Concert Band MPA, is there a correlation between ELA and Mathematics achievement scores and the level of music performed?

3. For the middle school students that did participate in the District Concert Band MPA, is there a correlation between ELA and Mathematics achievement scores and their band's overall rating received? 
The following statistical hypotheses were tested to answer the research questions:

Research Hypothesis 1: There is a statistically significant difference between a middle school student's District Concert Band MPA participation and ELA and mathematics achievement scores.

Research Hypothesis 2: There is a statistically significant difference between the students' ELA and mathematics achievement scores and the level of music performed by their respective band.

Research Hypothesis 3: There is a statistically significant difference between the students' ELA and mathematics achievement scores and their band's overall rating received.

Four Miami-Dade County Public Middle Schools were used for this study; two of the schools were high-achieving schools and the other two schools were low-achieving schools. Two samples of students were created for each school: Group 1 contained the students that participated in the Concert Band MPA and Group 2 was a stratified random sample of students from within the school that did not participate in the Concert Band MPA. An independent-samples $t$-test was used to test the three research hypotheses.

\section{Discussion of the Results}

This section will discuss the results that were revealed via the independentsamples $t$-tests at the alpha .05 level that were generated with SPSS 23.

\section{Discussion of Research Hypothesis 1}

Research Hypothesis 1 sought to test the difference between those students that participated in the Concert Band MPA versus those that did not regarding their FSA ELA and mathematics achievement scores. Table 17 listed the data for the high-achieving 
schools' independent-samples $t$-test. These data indicated that there was a statistically significant difference between the ELA achievement scores of those students that participated in the Concert Band MPA $(M=3.80, S D=.991)$ and those that did not participate $(M=2.54, S D=1.24) ; t(168)=7.47, p<.001$. These data also indicated that there was also a statistically significant difference between the mathematics achievement scores of those students that participated in the 2016 Concert Band MPA $(M=3.53, S D=$ $.76)$ and those that did not participate $(M=2.78, S D=.84) ; t(176)=6.30, p<.001$.

These data are supported by the notion of educating the whole child, as discussed in Chapter II. Even though it is not the fact that every student in a high-performing school is enrolled in a music course, these students are more likely to have an elective of some kind. Typically speaking, wealthier students are enrolled in high-achieving schools; wealthier students are enjoying a rich and varied curriculum and many opportunities to engage in the arts, whereas many of our less wealthy students spend their school days bent over worksheets in an effort to boost standardized test scores (Meier \& Wood, 2004; Noddings, 2005). These very strong results $(p<.001)$ can support the notion of the benefits of music education within the school's curriculum.

Table 18 listed the data for the low-achieving schools' independent-samples $t$-test. These data indicated that there was a statistically significant difference between the ELA achievement scores of those students that participated in the 2016 Concert Band MPA ( $M$ $=2.94, S D=1.18)$ and those that did not participate $(M=2.31, S D=1.05) ; t(126)=3.16$, $p=.002$. There was also a statistically significant difference between the mathematics achievement scores of those students that participated in the 2016 Concert Band MPA ( $M$ 
$=2.92, S D=1.01)$ and those that did not participate $(M=2.48, S D=.91) ; t(126)=2.57$, $p=.011$.

These data are also supported by the notion of educating the whole child. Typically speaking, the less-wealthier students are enrolled in low-achieving schools and as Noddings (2005) indicated, children are moral beings that must be provided with character education programs and are artistically inclined that must be provided arts classes, such as music. Students should not be excluded from the opportunity of taking courses such as music because of them having a low achievement score on a standardized test. The findings for the low-achieving schools indicate a positive correlation between music in school and high achievement scores; this quantifiable information can be used to inform administrators that music can be a possible viable school program used to positively affect student achievement within their school.

Table 19 combines the scores of all the four schools that were used in the study and listed the data for the independent-samples $t$-test. There was a statistically significant difference between the ELA achievement scores of those students that participated in the 2016 Concert Band MPA $(M=3.44, S D=1.15)$ and those that did not participate $(M=$ 2.44, $S D=1.17) ; t(304)=7.49, p<.001$. There was also a statistically significant difference between the mathematics achievement scores of those students that participated in the 2016 Concert Band MPA $(M=3.27, S D=.92)$ and those that did not participate $(M=2.65, S D=.88) ; t(304)=6.05, p<.001$.

These results support the literature that has been presented throughout this study. This ex post facto study, along with existing literature, suggests the positive link between music study and student achievement in school. These results suggest that a disservice 
may be done to our students when music programs are being cut from schools' curriculum due to budget and/or standardized testing.

This study focused on middle school education in particular and throughout this country, the biggest achievement gap is the transition from elementary to middle school (West \& Schwerdt, 2012). Additionally, Manning (2000) indicated that middle school students require school programs and practices that meet their unique developmental and educational needs. A developmentally responsive and successful middle level school shall provide a curriculum that is challenging, integrative, and exploratory (This We Believe, 1995). Music within the school context falls under the exploratory category.

The statistical results from this study, along with the existing literature, suggests that music can be a program that administrators should consider funding, offering, and supporting within their school. While allowing the middle school students to be enrolled in music courses, which serves as an outlet from the other core courses such as language arts and mathematics, the music courses can also support the overall student achievement efforts within the school.

\section{Discussion of Research Hypothesis 2}

Research Hypothesis 2 focused on the students that participated in the Concert Band MPA. This hypothesis sought to test the link between the students' ELA and mathematics scores and the level of music that they performed at the Concert Band MPA. Table 20 listed the independent-samples $t$-test data for the level of music performed. These data indicated that there was a statistically significant difference between the ELA achievement scores of those students that performed music from the MB level, which is the higher-level music $(M=3.80, S D=.99)$ and those that performed music from the MC 
level, which is the lower-level music $(M=2.94, S D=1.18) ; t(151)=-4.89, p<.001$. Additionally, there was a statistically significant difference between the mathematics achievement scores of those students that performed music from the MB level, which is the higher-level music $(M=3.53, S D=.76)$ and those that performed music from the MC level, which is the lower-level music $(M=2.92, S D=1.01) ; t(111)=-4.05, p<.001$.

In addition to the music level classification being based on the school's enrollment, the level of music that the students performed is also one indication of how long the students may have been studying music. As Demorest and Morrison (2000) indicated in their correlational study, the longer a student studied music, the greater their academic performance improved.

Out of all the students in secondary school (middle and high school) in the State of Florida enrolled in music classes, more students are enrolled in band than any other music course (Florida School Music Association, n.d.). Students usually start band instruction on the middle school level. If research shows that students who study music longer have a higher instance of improving academically than those who are not in music, then it would seem to be a disservice to cut middle school band programs. Unfortunately, this has been the case, especially when the sharp increase of high-stakes testing began. However, this study, particularly Research Hypothesis 2, along with other empirical studies, tentatively supports the notion that the longer a student studies music, the higher their academic achievement will probably be, not only on standardized testing, but also their academics in general (Wetter, Koerner, \& Schwaninger, 2009). 


\section{Discussion of Research Hypothesis 3}

Research Hypothesis 3 also focused on the students that participated in the Concert Band MPA. This hypothesis sought to test the relationship between the students' ELA and mathematics scores and the overall final rating that their band received at the Concert Band MPA. Table 21 listed the independent-samples $t$-test data for the level of music performed. These data indicated that even though the mean of the ELA achievement scores of those students whose band received a final rating of superior ( $M=$ 3.52, $S D=1.12$ ) was higher than those students whose band received a final rating of good $(M=3.34, S D=1.19)$; there was not a statistically significant difference $t(151)=$ $.94, p>.05$. Additionally, the mean of the mathematics achievement scores of those students whose band received a final rating of good $(M=3.37, S D=.82)$ was actually higher than those students whose band received a final rating of superior $(M=3.19, S D=$ .99); yet, there was not a statistically significant difference $t(151)=-1.20, p>.05$.

Research Hypothesis 3 sought to analyze the quality of the band program in terms of their final overall rating at the Concert Band MPA and determine if the rating has an overall effect on the students' ELA and mathematics achievement scores. The mean of the ELA scores, although not statistically significant, was slightly higher for the students that participated in the Concert Band MPA than those who $\operatorname{did} \operatorname{not}(M=3.52$ vs $M=$ 3.34). Although speculatory, these means showed perhaps an effect on the ELA scores; this is an important observation to consider because the literature states that literacy acquisition and learning is a primary focus among educators (Register et al., 2007). The results dealing with the mathematics achievement scores, although not statistically significant, seemed to contradict the hypothesis; the mean of the students' mathematics 
achievement score whose band received an overall final rating of good was higher than those whose band received an overall final rating of superior. This contradiction of the hypothesis could also be a result of the limitation listed in Chapter I, which referenced the quality of the band director.

\section{Implications}

Based on the discussion of the three research hypotheses' results, the next section will highlight the theoretical, research, and practical implications of the study.

\section{Theoretical Implications}

The theoretical implications that this study focuses on is Howard Gardner's theory of multiple intelligences. The human mind goes beyond linguistic and mathematical skills and these seem to be the only two areas that standardized testing assess. Howard Gardner's theory of multiple intelligences suggests that the human mind can possess up to nine different intelligences; one of those intelligences is music (Gardner \& Hatch, 1989). Schools are responsible for tapping into these different intelligences, as educators are charged with the task of reaching ALL of the learners within their classroom and as the theory suggests, students learn in different ways and they have different strengths and weaknesses. Griggs et al. (2009) mentions that as educators attempt to engage students in a variety of ways, knowing which intelligences students possess is critical to effective instruction.

The results of this study enriches in what we already knew about the theory of multiple intelligences, in that there was a strong evidence of the positive effect of participating in the Concert Band MPA and student achievement on the ELA and mathematics subtests of the FSA. As McFarlane (2011) mentioned, music intelligence 
parallels linguistic intelligence and additionally, as Gardner (2011) suggested, mathematical and musical intelligences may share common thinking processes. The findings of this research therefore seem to support these notions, at least preliminarily.

\section{Research Implications}

The advocacy for music education in school extends all the way back to 1838 when Lowell Mason persuaded the Boston School Committee to include music as a curricular subject; to this day, advocacy has continually informed society and policymakers of the value of music education in the schools (Mark, 2002). There is extensive correlational and ex post facto research that explores the connection between music education in school and high student achievement and this correlational study sought to contribute to the existing literature. Because students, when transitioning from elementary to middle school exhibit the largest instance of an achievement gap (West \& Schwerdt, 2012), administrators are charged with the responsibility of closing the achievement gap and the research can support the notion that music education could be a program used within the school to assist in closing the achievement gap.

Not only does music seem to be linked to high student achievement, it also can contribute to students' social skills, which are crucial to successfully function in society and in life (Gooding, 2009). Additionally, music education in schools can contribute to higher matriculation rates, higher rates of acceptance into medical schools, lower rates of current and lifetime alcohol, tobacco, or drug abuse, and lower rates of disruptive classroom behaviors (Aschaffenburg \& Maas, 1997; National Center for Educational Statistics, 1997; Southgate \& Roscigno, 2009; Texas Commission on Drug and Alcohol Abuse, 1999; Thomas, 1994). 
All of this ties into the notion of educating the whole child. Schools are supposed to be designed to serve both the individual and the larger society as a whole... society wants people that exhibit sound character, have a social conscience, think critically, are willing to make commitments, and are aware of global problems; those schools that only focus on standardized test scores in reading and mathematics do not effectively educate the whole child (Noddings, 2005; Soder et al., 2001).

\section{Implications for Practice}

School administrators may want to make a concerted effort to ensure that based on these findings, as well as other existing studies, all students, regardless of achievement level, may benefit significantly from the opportunity to study music. Administrators should not allow students to be excluded from studying music just because they are not on achievement level according to a standardized test. Administration should explore different ways of integrating music (and other arts / electives) into the overall school's curriculum so that they can all work together in sync to raise student achievement; this idea created the notion of the STEAM (Science, Technology, Engineering, the Arts, and Mathematics) initiative, which is currently being used in our schools today as the educational approach to student instruction.

\section{Recommendations for Further Research}

Even though this study supported existing research that links music study to academic achievement, additional questions can emerge and further research can also be recommended. The following recommendations for further research can further develop and support the findings of this study. 
1. To further test the findings of this study, additional research can be conducted at other middle schools throughout the Miami-Dade County Public School System that has band programs. Additional research can also be conducted at other school districts throughout the U.S. with similar socioeconomics.

2. Because the existing research identifies a correlation between music study in general and student achievement, a similar study can be conducted with chorus programs as well as orchestra programs throughout Florida, as these programs also participate in Music Performance Assessments in the State of Florida.

3. There are cases in Miami-Dade County Public Elementary Schools, particularly in the low-performing ones, where students are not afforded the opportunity to attend music class because they are not on "achievement level" in accordance to the FSA. A similar study can be conducted in these elementary schools to compare the FSA scores of those students that have music class versus those that do not.

4. A similar study can be conducted in the various senior high schools to compare the FSA scores of those students that are in the band (orchestra, or chorus) programs to those students who are not.

5. Jazz is a musical artform that requires creativity on the musician's part. In a jazz ensemble, the musician is expected to be able to improvise (create) a solo on the spot while being accompanied by the rest of the band in the background. Since improvisation requires a greater skill of creativity, a similar study can be conducted to compare the FSA scores of those students that are in their school's jazz ensemble to those students who are not. 
6. A study can be conducted to observe the social effects that music study has on students; examples of these may include students' social skills, as Gooding (2009) mentioned that strong social skills are vital for successful functioning in life, such as getting along with others, developing meaningful relationships, academic success, and discovering who they are as a person.

7. Culture refers to learned, accumulated experiences and to those socially transmitted patterns for behavior characteristic of a particular social group (Birukou, Blanzieri, Giorgini, \& Giunchiglia, 2013; Keesing, 1981). Band, orchestra, and chorus programs possess characteristics of a culture and a study could be conducted to observe the social effects these music programs have on students in terms of motivation to do well in school as well as social / behavioral skills towards others.

\section{Summary}

Chapter 5 finalized this study with the discussion of the results, the implications of theory, research, and practice, as well as recommendations for further research. The results of this study showed a statistically significant difference between those students that participated in the District Concert Band MPA and those that did not regarding their achievement scores on the ELA and mathematics subtests of the FSA. There was also a statistically significant difference between the students' ELA and mathematics achievement scores and the level of music that they performed at the District Concert Band MPA. However, there was not a statistically significant difference between the students' ELA and mathematics achievement scores and their band's overall final rating received at the District Concert Band MPA. 
The results of this study supported Howard Gardner's theory of multiple intelligences as well as other existing empirical research which suggests a connection between music study in school and high academic achievement. Further research should be conducted to observe the effects of music study in school on student achievement with other music education branches such as orchestra and chorus, as well as other grade levels such as elementary school and senior high school. The information that this study presented with its results should be used as additional research for school and district administrators when making decisions as to which programs should be offered, retained, and funded in their schools to assist with overall student achievement efforts in education. Not only correlational studies suggest that there is a connection between music study and high student achievement, music education can also support the notion of educating the whole child—which is something that all schools and educators should strive for to effectively educate and prepare our future citizens of society. 


\section{REFERENCES}

Abril, C. R., \& Gault, B. M. (2008). The state of music in secondary schools: The principal's perspective. Journal of Research in Music Education, 56, 68-81.

Alexander, W. M., \& Williams, E. (1968). The emergent middle school. New York, NY: Holt, Rinehart, and Winston.

American Music Conference. (2003). Press Releases. Carlsbad, CA: American Music Conference.

Aschaffenburg, K. \& Maas, I. (1997). Cultural and educational careers: the dynamics of social reproduction. American Sociological Review, 62, 573-87.

Birukou, A., Blanzieri, E., Giorgini, P., \& Giunchiglia, F. (2013). A formal definition of culture. Springer Science + Business Media, New York, NY.

Bryan, S. L., \& Dorrington, A. E. L. (2004). Improving math achievement of at-risk learners. Phi Delta Kappa Fastbacks, 518, 3-39.

Butterworth, B. (2005). The development of arithmetical abilities. Journal of Child Psychology and Psychiatry, 46, 3-18.

Compton, M. F. \& Hawn, H. C. (1993). Exploration: The total curriculum. Columbus, OH: National Middle School Association.

Cooper, S. (2010). Lighting up the brain with songs and stories. General Music Today, 23, 24-30.

Demorest, S. M., \& Morrison, S. J. (2000). Does music make you smarter? Music Educators Journal, 87, 33-39.

Ediger, M. (2006). Present day philosophies of education. Journal of Instructional Psychology, 33, 179-182.

Ehri, L., Nunes, S., Willows, D., Schuster, B., Yaghoub-Zadeh, Z., \& Shanahan, T. (2001). Phonemic awareness instruction helps children learn to read: Evidence from the National Reading Panel's meta-analysis. Reading Research Quarterly, 36, 250287.

Fehr, R. C. (2006). Principals say music programs affect graduation. Teaching Music, 14(2), 16.

Field, A. (2009). Discovering statistics using SPSS ( $3^{\text {rd }}$ ed.)Thousand Oaks, CA: Sage. 
Florida Bandmasters Association (FBA). http://flmusiced.org/fba/dnn/AboutFBA/Philosophy (n.d.)

Florida Department of Education's Office of Accountability and Policy Research. http://www.fldoe.org/accountability (n.d.)

Florida School Music Association (FSMA). http://fsma.flmusiced.org/about (n.d.)

Florida School Music Association's (FSMA) Music Performance Assessment (MPA) Database. https://flmusiced.org/MPAOnline/PublicReports/MPAMenu.aspx (n.d.)

Foorman, B., Fletcher, J., \& Francis, D. (1997). A scientific approach to reading instruction. Learning Disabilities Online. Retrieved from http://www.ldonline.org/article/6251

Gallagher, L. (2001). Does classical music really affect spatial-temporal ability? National Undergraduate Research Clearinghouse, 4. Retrieved from http://www.webclearinghouse.net/volume/4/GALLAGHER-DoesClassi.php

Gardner, H. (2011). Nine types of multiple intelligences. Retrieved from http://skyview.vansd.org/lschmidt/Projects/The\%20Nine\%20Types\%20of\%20Intelli gence.htm

Gardner, H., \& Hatch, T. (1989). Educational implications of the theory of multiple intelligences. Educational Researcher, 18(8), 4-10.

Geist, K., \& Geist, E. A. (2008). Do re mi, 1-2-3: That's how easy math can be: Using music to support emergent mathematics. YC Young Children, 63(2), 20-25.

Gilstrap, R. L. (1994). Professional books -- exploration: The total curriculum by Mary F. Compton and Horace C. Hawn. Childhood Education, 70, 252.

Gooding, L. (2009). Enhancing social competence in the music classroom. General Music Today, 23, 35-38.

Goodlatte, B. (2001). And music for all. MENC: The National Association for Music Education, 51, 23-24.

Griggs, L., Barney, S., Brown-Sederberg, J., Collins, E., Keith, S., \& Iannacci, L. (2009). Varying pedagogy to address student multiple intelligences. Human Architecture, 7, $55-60$.

Gromko, J. E. (2005). The effect of music instruction on phonemic awareness in beginning readers. Journal of Research in Music Education, 53, 199-209. 
Jefferson, T. (1818). Report of the commissioners for the University of Virginia. August 4, 1818. Retrieved from http://etext.virginia.edu/etcbin/toccer-new2?id=JefPapr.sgm \&images $=$ images $/$ modeng\&data $=/$ texts/english/modeng/parsed\&tag=public\&part= $14 \&$ division $=\operatorname{div} 1$

Johnson, P. B. (2004). The relationship between average SAT scores (total, verbal, and math) and concert festival participation in South Carolina public high schools. Retrieved from http://ezproxy.fiu.edu/login?url=http://search.proquest.com/docview/ 305049764? accountid=10901

Kalish, N. (2010). Why art makes kids smarter. Parenting Magazine. Retrieved from http://www.parenting.com/article/why-art-makes-kids-smarter

Keesing, R. M. (1981). Cultural anthropology: A contemporary perspective. New York: Holt, Rinehart and Winston.

Kliebard, H. (1995). The struggle for the American curriculum. New York, NY: Routledge.

Manning, M. L. (2000). A brief history of the middle school. The Clearing House, 73, 192.

Mark, M. L. (1989). A new look at historical periods in American music education. Bulletin of the Council for Research in Music Education, 99, 1-6.

Mark, M. L. (2002). A history of music education advocacy. Music Educators Journal, $89,44-48$.

McFarlane, D. A. (2011). Multiple intelligences: The most effective platform for global 21 st century educational and instructional methodologies. College Quarterly, 14, 8.

Meier, D., \& Wood, G. (2004). Many children left behind. Boston, MA: Beacon Press.

Music makes the grade: Music programs contribute to higher attendance and graduation rates. (2007). Teaching Music, 14(4), 4-36A,36B,36C,36D.

National Center for Educational Statistics (1997). National assessment of educational progress (NAEP) report card. Washington DC: National Center for Educational Statistics.

Noddings, N. (2003). Happiness and education. Cambridge, MA: Cambridge University Press.

Noddings, N. (2005). What does it mean to educate the WHOLE CHILD? Educational Leadership, 63, 8-13. 
Olson, C. A. (2009). Music and academic success go together at Whitworth; university's survey results also suggest high school music may boost chances of college admittance. Teaching Music, 16(6), 20.

Register, D., Darrow, A., Standley, J., \& Swedberg, O. (2007). The use of music to enhance reading skills of second grade students and students with reading disabilities. Journal of Music Therapy, 44, 23-37.

Rothstein, R. (2008). The corruption of school accountability. School Administrator, 65(6), 14-15.

Schon, D., Boyer, M., Moreno, S., Besson, M., Peretz, I., \& Kolinsky, R. (2008). Songs as an aid for language acquisition. Cognition, 106, 975-983.

Shetler, D. J. (1985). Prelude to a musical life: Prenatal music experiences. Music Educators Journal, 71, 26-27.

Silberman, C. E. (1973). The open classroom reader. New York, NY: Vintage Books.

Soder, R., Goodlad, J. I., \& McMannon, T. J. (2001). Developing democratic character in the young. San Francisco, CA: Jossey-Bass.

Southgate, D. E., \& Roscigno, V. J. (2009). The impact of music on childhood and adolescent achievement. Social Science Quarterly, 90, 4-21.

Summa-Chadwick, M. (2009). The power of music: The use of music protocols to enhance neurological function. Exceptional Parent, 39(7), 38-42.

Texas Commission on Drug and Alcohol Abuse (1999). Reported by first act. Houston Chronicle. January 11, 1999.

This we believe: Developmentally responsive middle level schools. A position paper (1995). National Middle School Association, 4151 Executive Parkway, Suite 300, Westerville, OH 43081.

Thomas, L. (1994). The case for music in the schools. Phi Delta Kappan. 75(6), 459.

West, M., \& Schwerdt, G. (2012). The middle school plunge. Education Next, 12(2), 6368

Wetter, O. E., Koerner, F., \& Schwaninger, A. (2009). Does musical training improve school performance? Instructional Science: An International Journal of the Learning Sciences, 37, 365-374. 
Woody, R. (1998). Music in the education of young children. Middle School Journal, 29, 41-47. 


\section{APPENDIX}

FLORIDA BANDMASTERS ASSOCIATION (FBA) ADJUDICATOR'S COMMENT SHEETS FOR THE

DISTRICT CONCERT BAND MUSIC PERFORMANCE ASSESSMENT (MPA) 


\section{FLORIDA BANDMASTERS ASSOCIATION \\ Adjudicator's Comment Sheet \\ CONCERT BAND}

School:

Classification:

Performance Time:

Date:

Selections: 1

2.

3.

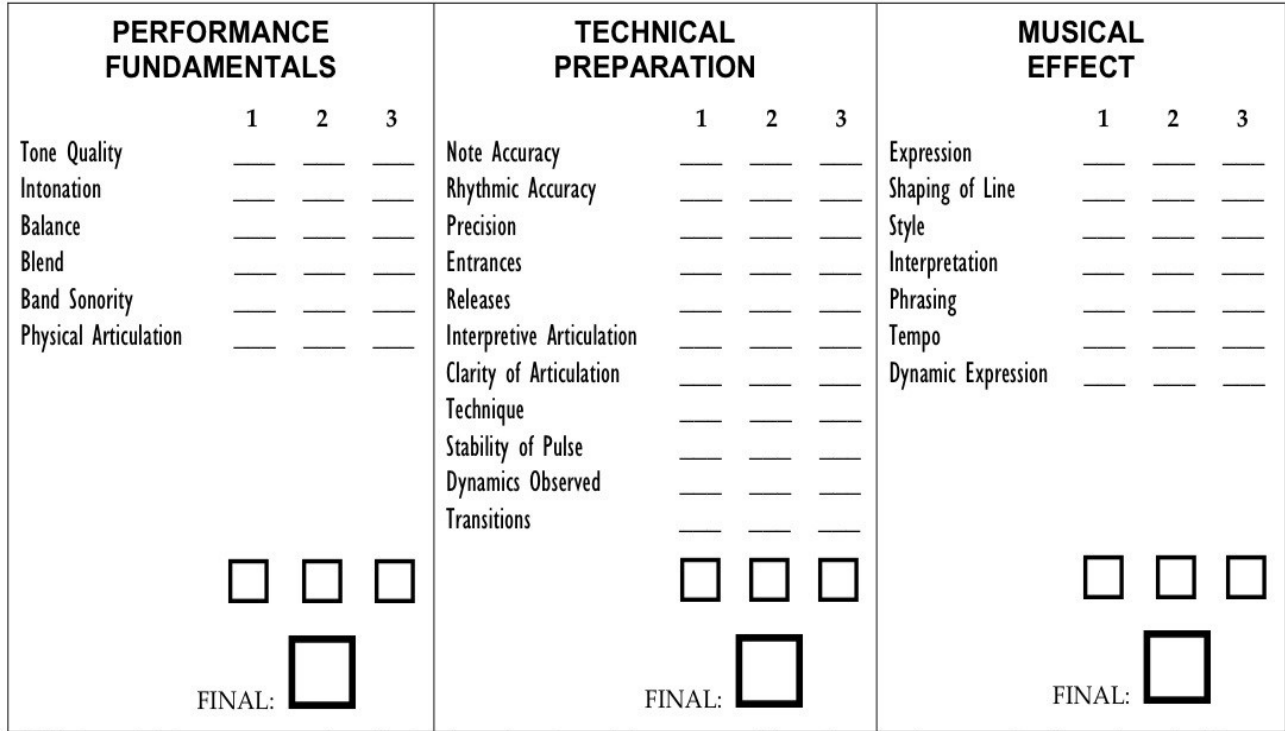

Officials may include a + or - next to items listed under each caption to indicate aspects of the performance that were noticeably good or noticeably needing improvement as related to the letter grade assigned. The absence of any marks indicates a performance consistent with the letter assigned. After completing the previous, enter an A, B, C, D or E to indicate the level of performance in each caption. Average the three letter grades in each caption to arrive at a final letter grade. Average the three final grades to arrive at the FINAL RATING.

\section{COMMENTS}

(Including: Stage Presence, Discipline, Posture, Instrumentation, Strong Points, Weak Points - Continue on Reverse Side $\Rightarrow$ )

Recommended for:

(Superior, Excellent, Good, Fair, Poor)

Write out Final Rating

Adjudicator's Signature 


\section{Florida Bandmasters Association}

Adjudicator's Comment Sheet

\section{SIGHT-READING}

School:

Band Name:
Classification:

Performance Time:

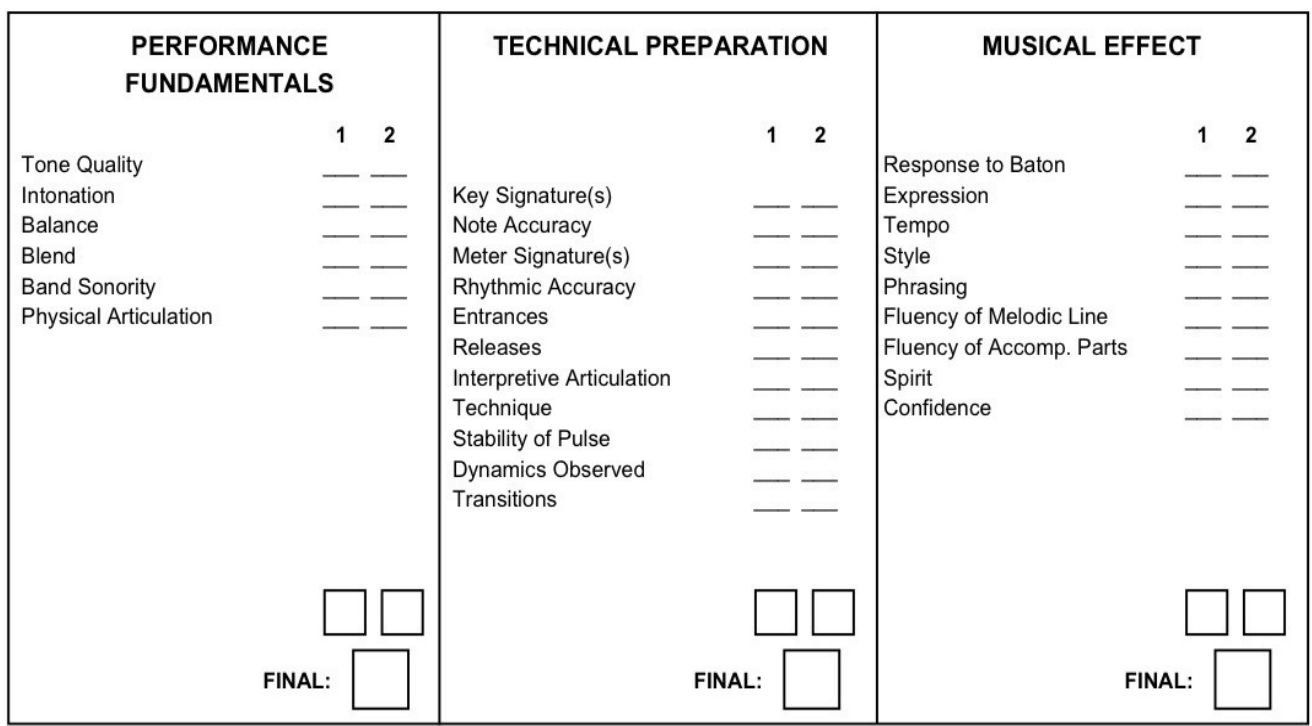

Officials will include a + or - by the subdivisions, which mean they are noticeably good or noticeably needing improvement as related to the letter grade assigned. The absence of any marks indicates a performance consistent with the letter assigned. After completing the previous, enter an A, B. C, D or E to indicate the level of performance in each category. Average the three letter grades in each category to arrive at a final letter grade. Average the three final grades to arrive at the FINAL RATING.

NOTE: The Overture is weighted heavier then the march due to the length and greater demands of musicianship COMMENTS

Recommended for 
VITA

\title{
ARTHUR JAMES NAPOLEON SCAVELLA
}

\author{
Born, Miami, Florida
}

2005

B.M., Music Education

Florida International University

Miami, Florida

$2005-2008$

Director of Bands and Orchestral Studies

Miami-Dade County Public Schools / Charles R. Drew Middle

School

Miami, Florida

2008

M.S., Educational Leadership

Florida International Leadership

Miami, Florida

2009

Director of Music

Miami-Dade County Public Schools / Oak Grove Elementary

School

North Miami, Florida

2009 - Present

Director of Bands / College Assistance Program (CAP) Advisor Miami-Dade County Public Schools / Arthur \& Polly Mays

Conservatory of the Arts

Miami, Florida

$2010-2018 \quad$ Doctoral Candidate

Educational Administration and Supervision

Florida International University

Miami, Florida

2016 - Present Certified Adjudicator

Florida Bandmasters Association (FBA)

State of Florida

\section{PRESENTATIONS}

Scavella, A.J.N. (2018). The Relationship Between District Concert Band Music Performance Assessment Participation and Student Achievement in Miami-Dade County Public Middle Schools. Presentation for the Graduate Student Appreciation Week Scholarly Forum at Florida International University. Miami, FL. 